\title{
KESANTUNAN BERBAHASA PARA PASANGAN CALON DALAM DEBAT CALON GUBERNUR-WAKIL GUBERNUR DKI JAKARTA KAJIAN SOSIOPRAGMATIK
}

\author{
Abdul Aziz \\ Pendidikan Bahasa Indonesia, Fakultas Pendidikan Agama Islam, STAI Nurul Ilmi Tanjung Balai \\ J1. Jend Soperapto, Muara Sentosa, Sei Tualang Raso, Kota Tanjung Balai, Medan, 21333 \\ E-mail : abdaaziz08@gmail.com
}

\begin{abstract}
ABSTRAK
Penelitian ini menjelaskan tingkat kesantunan berbahasa para pasangan calon gubernur dan wakil gubernur dari segi, jenis tindak tutur, gaya dan majas yang dituturkan, strategi bertutur, dan penerapan prinsip kesantunan oleh para paslon tersebut dalam Debat Pilkada DKI Jakarta. Berdasarkan hasil analisis data, didapat empat simpulan. Pertama, ditemukan lima jenis tindak tutur oleh para paslon dalam debat Pilkada DKI Jakarta, yaitu jenis tindak tutur ekspresif, dalam bentuk menyindir, mengkritik, mengeluh, mengecam; jenis tindak tutur representatif, dalam bentuk menyatakan, melaporkan, membual, menyebutkan, menjelaskan, memberitahukan; jenis tindak tutur direktif, dalam bentuk mempengaruhi, mengajak, menghimbau, memaksa, meyakinkan, meminta, menawarkan; jenis tindak tutur komisif, dalam bentuk menjanjikan; dan jenis tindak tutur deklaratif, dalam bentuk melarang. Jenis tindak tutur yang paling dominan digunakan adalah tindak tutur ekspresif dengan bentuk menyindir. Kedua, ditemukan tiga jenis majas sebagai pengungkap gaya berbahasa oleh para paslon, yaitu majas sarkasme, majas sinisme, dan majas ironi. Majas yang paling dominan digunakan adalah ironi. Ketiga, ditemukan empat strategi bertutur yang digunakan oleh para paslon, yaitu strategi bertutur, terus terang tanpa basa-basi, kesantunan negatif, kesantunan positif, dan strategi samar-samar. Strategi yang dominan digunakan oleh parapaslon adalah bertutur terus terng tanpa basa-basi (strategi bertutur langsung).Keempat, ditemukan pelanggaran secara dominan terhadap penggunaan enam prinsip kesantunan berbahasa dalam Debat Pilkada DKI Jakarta, yaitu pelanggaran terhadap prinsip kebijaksanaan, kedermawanan, pujian, kerendahan hati, kesepakatan, dan prinsip kesimpatikan, sedangkan pematuhannya sedikit sekali digunakan. Berdasarkan persentase temuan tersebut dapat disimpulkan bahwa penggunaan unsur kesantunan para paslon dalam Debat Pilkada DKI berada dalam tingkat keterancaman muka 'agak tinggi' dengan kategori 'kurang santun".
\end{abstract}

Kata Kunci: Kesantunan Berbahasa, Para Paslon, Debat Pilkada DKI Jakarta

\section{PENDAHULUAN}

Dalam fungsinya bahasa sebagai alat komunikasi bahasa sangat berperan membangun kebudayaan dan peradaban suatu bangsa. Sebab bahasa sebagai piranti sosial akan menggiring masyarakat pemakainya memiliki jati diri dan karakter berlandaskan nilai bahasa yang membentuknya. Semakin baik bahasa yang digunakan, semakin mudah maksud dan pesan yang diterapkan, sebaliknya, semakin tidak terkendali bahasa yang digunakan maka semakin meluas bahasa yang dimunculkan. Pelanggaran kesantunan dalam berbahasa pada dekade terakhir ini tampaknya menjadi fenomena yang cukup serius dalam dunia politik.

Pelanggaran kesantunan dalam berbahasa pada dekade terakhir ini tampaknya menjadi fenomena yang cukup serius dalam dunia politik. Hal tersebut ditunjukkan dari banyaknya penelitian yang membahas hal tersebut, di antaranya di USA (Noulizarvin. P, 2011; (Wacker, 2011); (Grebelsky, 2014), dan di Prancis (Fracchiolla. B, 2011;). Penelitian lain tentang hal itu di Indonesia menunjukkan bahwa bahasa dalam dunia politik hampir kehilangan makna karena sudah menjadi sarana untuk mengumpat, mencaci maki,, menyerang, bahkan menjatuhkan orang lain atau lawan politik (Agustina, 2017). Hal tersebut juga dibuktikan dari beberapa hasil penelitian, seperti di Persia (Papacharissi, 2014); (Rakzadian, 2012), di Jepang (Smith, 2011; (Dicket, 2011), di Turki (Yethin, 2015), di Italia (Joseph, 2011).

Sosio berhubungan dengan masyarakat dan linguistik adalah kajian bahasa. Jadi, sosiolinguistik merupakan kajian tentang bahasa yang dikaitkan dengan kondisi kemasyarakatan. Hasil penggabungan antara disiplin ilmu sosiolinguistik dan disiplin ilmu pragmatik disebut sosiopragmatik. Jadi, sosiopragmatik merupakan penggabungan dua disiplin ilmu yaitu sosiologi dan pragmatik yang mengkaji tuturan dan mengaitkannya dengan konteks sosial. Hal ini membuat hasil analisis data yang lebih tepat jika dikaji menggunakan kajian sosiopragmatik imperatif yang mendalami makna tuturan tidak hanya dari aspek situasi pada saat tuturan berlangsung, juga memperhatikan keadaan sosial.

Kesantunan berbahasa sangat perlu untuk dikaji, karena kegiatan berbahasa tidak luput dari kehidupan 
manusia. Kesantunan merupakan sebuah istilah yang berkaitan dengan kesopanan, rasa hormat, sikap yang baik atau, perilaku yang pantas. Dalam kehidupan seharihari, keterkaitan kesantunan dengan perilaku yang pantas mengisyaratkan bahwa kesantunan bukan hanya berkaitan dengan bahasa, melainkan juga dengan perilaku nonverbal. Kesantunan menghubungkan bahasa dengan berbagai aspek dalam struktur sosial sebagaimana hanya dengan aturan perilaku atau etika. Sopan santun dalam bentuk tuturan atau kesantunan berbahasa setidaknya bukan semata-mata motivasi utama bagi penutur untuk berbicara, melainkan juga merupakan faktor pengatur yang menjaga dengan benar, menyenangkan dan tidak sia-sia. Pemilihan kesantunan berbahasa dalam debat pilkada calon gubernur dan wakil gubernur DKI Jakarta dimaksud untuk mengetahui, diksi sebagai pengungkap gaya bahasa, jenis tindak tutur, strategi bertutur dan kesantunan berbahasa yang digunakan dalam debat calon gubernur dan wakil gubernur DKI Jakarta 2017. Kesantunan berbahasa dalam debat cagub dan cawagub yang dipilih dapat dijadikan sebagai objek penelitian. Penelitian terhadap kesantunan berbahasa dalam debat selalu ada ditiap forum diskusi, sehingga hal tersebut menjadi hal yang unik serta menarik perhatian peneliti.

Berdebat berarti berbicara kepada lawan bicaranya untuk membela atau menyerang pendapatnya, saling beradu kepandaian dan logika. Dalam konteks pemilu, debat saling beradu kepandaian dan logika membahas suatu masalah daerah pemilih dengan menyampaikan visi, misi, rencana, program, dan argumen-argumen oleh calon pejabat/peserta debat. Sehubungan dengan situasi tersebut, secara sadar maupun tidak sadar peserta debat tersebut telah melakukan kegiatan berbahasa dengan berposisi sebagai penutur dan mitra tutur. Penutur sebagai orang yang bertutur, yaitu orang yang menyatakan fungsi pragmatis tertentu di dalam peristiwa komunikasi. Mitra tutur orang yang menjadi sasaran sekaligus kawan penutur di dalam penuturan. Peran penutur dan mitra tutur dilakukan silih berganti dalam sebuah tindak tutur. Pelaku tuturan yang semula berperan sebagai penutur pada tahap tuturan berikutnya dapat menjadi mitra tutur begitu juga sebaliknya. Menurut (Tarigan, 2011) debat adalah saling adu argumentasi antar pribadi atau antar kelompok manusia dengan tujuan mencapai kemenangan satu pihak.

Debat adalah suatu proses komunikasi yang dilakukan secara lisan yang dinyatakan dengan bahasa untuk mempertahankan gagasan atau pendapat (Asidi, 2015)

Dalam berdebat sering ditemukan elit politik kurang memperhatikan prinsip kesantunan atau etika dalam berbahasa. Akibatnya, komunikasi menjadi terganggu, karena salah satu pihak yang terlibat dalam komunikasi merasa disinggung, direndahkan, diremehkan dan sebagainya. Misalnya, dalam kegiatan seminar, diskusi, bahkan debat politik yang sering disaksikan dalam televisi, ketika mengajukan pertanyaan, menyela, memberi saran, memberi informasi, menyampaikan kritik, memberikan jawaban atas pertanyaan atau tanggapan menggunakan bahasa yang kurang santun. Hal tersebut terjadi karena penutur tidak memperhatikan siapa yang diajak berbicara sehingga dengan seenaknya penutur memilih kata-kata yang kurang sopan dan kasar.

Pragmatik merupakan suatu istilah yang mengacu pada penggunaan bahasa atau membahas bagaimana penggunaan bahasa yang sesuai dengan konteks pemakaiannya. Menurut (Agustina 2017). Sosiopragmatik merupakan telaah mengenai kondisikondisi atau kondisi-kondisi 'lokal' yang lebih khusus ini jelas terlihat bahwa prinsip kerja sama dan prinsip kesopanan berlangsung secara berubah-ubah dalam kebudayaan yang berbeda-beda atau aneka masyarakat bahasa, dalam situasi sosial yang berbeda-beda dan sebagainya. Artinya dengan perkataan lain, sosiopragmatik merupakan tapal batas sosiologis pragmatik. Jadi, jelas disini betapa erat hubungan antara sosiopragmatik dengan sosiologi (Tarigan, H. G, 2011).

Tindak tutur merupakan suatu analisis yang bersifat pokok dalam kajian pragmatik. Pendapat tersebut berkaitan dengan objek kajian pragmatik yang sebagian besar berupa tindakan tuturan dalam peristiwa komunikasi. Dalam analisis pragmatik objek yang dianalisis adalah objek yang berkaitan dengan penggunaan bahasa dalam peristiwa komunikasi, yaitu berupa ujaran atau tuturan yang diidentifikasikan maknanya dengan menggunakan teori pragmatik (Halid, 2011). Menurut (Chaer \& Leonie 2012) menyatakan bahwa tindak tutur merupakan gejala individual, bers ifat psikologis dan keberlangsungannya ditentukan oleh kemampuan bahasa si penutur dalam menghadapi situasi tertentu

Jenis-jenis tindak tutur antara lain: tindak tutur berdasarkan modus deklaratif terdapat dua tindak tutur konstatif dan tindak tutur performatif. Tindak tutur berdasarkan objeknya terdapat tiga bagian yaitu, tindak tutur lokusi, tindak tutur ilokusi dan tindak tutur perlokusi. Tindak tutur berdasarkan modus terdapat lima yaitu, tindak tutur representatif, tindak tutur direktif, tindak tutur ekspresif, tindak tutur komisif dan tindak tutur deklaratif, tindak tutur berdasarkan langsung, tidak langsung, tindak tutur berdasarkan harfiah dan tidak harfiah tindak tutur berdasarkan sudut pandang kelayakan pelakunya. (Chaer, 2012)

Menurut (Chaer, 2012) dalam bukunya yang berjudul Politeness: Some Universal in Language Usage mengemukakan bahwa terdapat lima strategi bertutur yakni, strategi langsung tanpa basa-basi, strategi kesantunan positif, strategi kesantunan negatif, strategi kesantunan tidak langsung, strategi bertutur dalam hati. Kesantunan berbahasa merupakan cara seseorang bertutur dan bertingkah laku terhadap mitra tutur dengan nilai-nilai yang terkandung di dalam masyarakat. Kesantunan itu berkaitan dengan konsep ,citra diri, (face) mengacu kepada ciri-ciri dari positif dan citra diri negatif. Prinsip-prinsip kesantunan terdiri dari enam maksim yaitu, maksim kebijaksanaan, maksim 
kederwanan, maksim pemufakatan, maksim penghargaan, maksim kesederhanaan, dan maksim kesimpatian. Di dalam model kesantunan setiap maksim interpersonal itu dapat dimanfaatkan untuk menentukan peringkat kesantunan sebuah tuturan

Kesantunan berbahasa merupakan cara seseorang bertutur dan bertingkah laku terhadap mitra tutur dengan nilai-nilai yang terkandung di dalam masyarakat. (Markhamah \& Atiqa, 2013) menyatakan bahwa kesantunan merupakan suatu cara yang dilakukan penutur saat berkomunikasi supaya penutur tidak merasa tertekan, tersudut, dan tersinggung. Kesantunan berbahasa dalam hal ini berupaya untuk menjaga harga diri pembicara maupun pendengar. Penggunaan bahasa yang santun saat berkomunikasi akan membuat mitra tutur dan lawan bicara merasa dihormati, nyaman, dan tidak menimbulkan kesalah pahaman. Menurut (Zamzani, dkk, 2012) kesantunan (politeness) merupakan perilaku yang diekspresikan dengan cara yang baik atau beretika. Kesantunan merupakan fenomena kultural, sehingga apa yang dianggap santun oleh suatu kultur mungkin tidak demikian halnya dengan kultur yang lain. Tujuan kesantunan, termasuk kesantunan berbahasa, adalah membuat suasana berinteraksi menyenangkan, tidak mengancam muka dan efektif.

(Keraf, 2014) mengemukakan bahwa gaya atau khususnya gaya bahasa dikenal dalam retorika dengan istilah style. Kata style diturunkan dari kata latin stilus, yaitu semacam alat untuk menulis pada lempengan lilin. Keahlian menggunakan alat ini akan mempengaruhi jelas tidaknya tulisan pada lempengan tadi. Kelak pada waktu penekanan dititik beratkan pada keahlian untuk menulis indah, maka style lalu berubah menjadi kemampuan dan keahlian untuk menulis atau mempergunakan kata-kata secara indah. Gaya bahasa adalah cara pengucapan bahasa dalam prosa atau bagaimana seorang pengarang mengungkapkan sesuatu yang akan dikemukakan

Ada sekitar 60 buah gaya bahasa yang dapat diklasifikasikan ke dalam empat kelompok besar, yaitu gaya bahasa perbandingan, gaya bahasa sindiran, gaya bahasa pertautan, dan gaya bahasa perulangan. (Keraf, 2014) ada beberapa jenis majas yang termasuk dalam kelompok gaya bahasa sindiran, yaitu, sarkasme, sinisme, ironi. Majas sarkasme adalah suatu majas yang dimaksudkan untuk menyindir, atau menyinggung seseorang atau sesuatu. Sarkasme dapat berupa penghinaan yang mengekspresikan rasa kesal dan marah dengan menggunakan kata-kata kasar. Majas ini dapat melukai perasaan seseorang. Dalam bahasa Indonesia, arti sarkasme berbeda dari kepercayaan banyak orang bahwa sarkasme berarti penyindiran yang menggunakan kata yang terbalik dari maksudnya, seperti ironi. Majas sinisme adalah menyatakan suatu pernyataan yang ditujukan untuk menyindir akan hal yang dilakukan oleh seseorang, atau penyampaian langsung diutarakan di depan objek yang disindir atau antara pembicaraan dengan orang ketiga. Majas ironi adalah majas yang tergolong dalam jenis majas pertentangan. Hal ini dipengaruhi adanya ungkapan gaya bahasa yang bertentangan dengan arti sesungguhnya. Selain majas pertentangan, ironi juga dapat digolongkan ke dalam jenis majas fungsinya yang digunakan untuk menyindir lawan bicara. Majas ironi adalah majas yang menyatakan makna yang bertentangan dengan maksud untuk menyindir.

Menurut (Wareing \& Linda, 2013), politik adalah masalah kekuasaan untuk membuat keputusan mengendalikan sumber daya manusia, mengendalikan perlakuan orang lain, dan mengendalikan nilai-nilai yang dianut orang lain. Dalam wikipedia Indonesia politik adalah proses pembentukan dan pembagian kekuasaan dalam masyarakat yang antara lain berwujud proses pembuatan keputusan, khususnya dalam negara. Orang yang ahli dalam bidang politik ini dikenal dengan sebuah politisi. Sedangkan pelaku yang berperan dan berkecimpung dalam ini disebut politikus. Debat adalah saling adu argumentasi antar pribadi atau antarkelompok manusia, dengan tujuan mencapai kemenangan antara satu pihak. Debat adalah pembahasan atau pertukaran pendapat mengenai suatu hal dengan saling memberi alasan untuk mempertahankan pendapat masing-masing.

\section{RUANG LINGKUP}

Permasalahan di dalam debat calon gubernur dan wakil gubernur DKI Jakarta memiliki kajian yang sangat luas. Karena berbagai kendala teknis dan waktu pengerjaan penelitian yang tidak memadai, maka dalam penelitian ini hanya dikaji dari kesantunan berbahasa para paslon gubernur dan wakil gubernur dalam Debat Pilkada DKI Jakarta dari segi jenis tindak tutur, penggunaan majas sebagai gaya pengungkapan strategi bertutur yang dipilih, dan apakah prinsip kesantunan dipatuhi atau dilanggar oleh para paslon dalam Debat Pilkada DKI. Berdasarkan pengkajian terhadap unsurunsur kesantunan tersebut dengan akhirnya dapat direpresentasikan tingkat kesantunan para paslon dalam Debat Pilkada DKI Jakarta 2017

\section{BAHAN DAN METODE}

Penelitian ini merupakan penelitian kualitatif dengan metode deskriptif. Penelitian kualitatif didefinisikan sebagai metode penelitian ilmu-ilmu sosial dalam kajian sosiopragmatik yang mengumpulkan dan menganalisis data berupa kata-kata (lisan maupun tulisan) dan perbuatan-perbuatan manusia seperti, tuturan, gaya bahasa, kesantunan berbahasa dan strategi bertutur. (Afrizal,2014). Metode penelitian yang digunakan adalah teknik deskriptif kualitatif. Subjek penelitian ini adalah paslon cagub dan cawagub DKI Jakarta yang mengikuti Debat Pilkada DKI dalam pemilu putaran satu dan putaran dua. Pada putaran satu diikuti debat dilakukan satu kali yang diikuti oleh tiga paslon, yaitu paslon Agus Harimurti Yudoyono- Silvy (Agus-Silvi), paslon AhokDjarot, dan paslon Anis-Sandi; sedangkan pada putaran 
kedua debat dilakukan tiga kali diikuti oleh dua paslon, yaitu, paslon Ahok-Djarot, dan paslon Anis-Sandi yang dijadikan sebagai subjek penelitian debat dalam kajian sosiopragmatik. Objek dalam penelitian ini adalah majas sebagai pengungkap gaya bahasa, jenis tindak tutur, strategi bertutur dan prinsip kesantunan serta tingkat kesantunan yang terdapat pada debat cagub dan cawagub pilkada DKI Jakarta.

Penelitian dengan pendekatan kualitatif menekankan analisis tuturan atau atau kalimat-kalimat yang memuat unsur-unsur kesantunan yang digunakan sebagai objek penelitian ini, yang terdapat dalam acara Debat Pilkada DKI Jakarta 2017 dengan menggunakan kajian sosiopragmatik. Dari pemilu putaran satu sampai putaran 2 dengan jumlah empat kali debat. Sumber data penelitian adalah media massa yang merelay acara debat, yaitu beberapa stasiun televisi supaya didapat rekaman debat secara utuh. Instrumen dalam penelitian ini adalah peneliti itu sendiri yang dibantu dengan beberapa format penelitian, yaitu format transkripsi data, identifikasi data, dan klasifikasi data,. Selain itu, penelitian ini juga menggunakan alat bantu untuk mengunduh data dari beberapa stasiun televisi untuk mengambil rekaman video acara Debat Pilkada DKI Jakarta 2017. Teknik pengumpulan data dalam penelitian ini menggunakan teknik dokumentasi. Data yang akan diteliti sudah didokumentasikan sebelumnya, hal ini bertujuan untuk membantu penulis dalam memperoleh data yang diinginkan. Pengambilan data dalam penelitian ini dilakukan dengan cara pencatatan kesantunan berbahasa berupa penggalan dialog yang mempunyai konteks utuh. Data diidentifikasi berdasarkan empat aspek, jenis tindak tutur, majas sebagai pengungkap gaya bahasa, strategi bertutur dan prinsip kesantunan, data dikumpulkan dan diurutkan secara sistematis berdasarkan format data identifikasi dan klasifikasi yang telah ditentukan

\section{PEMBAHASAN}

Berdasarkan hasil penelitian ditemukan penggunaan gaya bahasa, jenis tuturan, strategi bertutur dan prinsip kesantunan oleh pasangan calon dalam debat pilkada DKI Jakarta. Kesantunan berbahasa berperan penting pada paslon dalam debat, baik dari segi jenis gaya bahasa dan strategi bertutur yang digunakan maupun prinsip kesantunan. Bertolak dari hasil analisis data terhadap empat unsur kesantunan sebagai pengungkap gaya bahasa, jenis tindak tutur, strategi bertutur dan prinsipprinsip kesantunan yang ditetapkan sebagai objek kajian dalam penelitian ini. Dari hasil analisis data berdasarkan tingkat kesantunannya dari yang tinggi, sedang dan rendah paslon memilih diksi sarkasme sebagai tingkat tertinggi dengan jumlah 4 data, tingkat kesantunan yang agak mendominasi pada sinisme dengan jumlah 27 data dan ironi dengan jumlah 55 data. Dari hasil analisis data berdasarkan tingkat kesantunannya dari yang tinggi, sedang dan rendah paslon memilih jenis tuturan ekspresif sebagai tingkat tertinggi dengan jumlah 35 data, tuturan direktif 10 data tingkat kesantunan yang agak mendominasi pada jenis tuturan komisif 7 data dan tingkat kesantunan kurang mendominasi jenis tuturan representatif 33 data dan jenis tuturan deklaratif 1 data.

Tabel 1 hasil analisis data menjelaskan berdasarkan tingkat kesantunannya dari yang tinggi, sedang dan rendah paslon memilih strategi bertutur terus terang tanpa basasi sebagai tingkat tertinggi dengan jumlah 31 data, tingkat kesantunan yang agak mendominasi pada strategi bertutur kesantunan negatif 22 data dan tingkat kesantunan kurang mendominasi strategi bertutur kesantunan positif 17 data dan strategi bertutur samarsamar 16 data. Maka jika diukur berdasarkan skala kesantunan tingkat tertinggi tuturan berada pada tindakan yang mengancam muka, (Face Threatening Acts) terdapat pada strategi bertutur terus terang tanpa basasi, tuturan berada keterancaman muka yang tinggi terdapat pada strategi bertutur kesantunan negatif dan strategi bertutur kesantunan negatif tuturan berada keterancaman muka yang kurang tinggi terdapat pada strategi bertutur samar-samar. Dari hasil analisis data berdasarkan tingkat kesantunannya dari yang tinggi, sedang dan rendah paslon memilih maksim kedermawanan 8 data sebagai tingkat tertinggi, maksim pujian 1 data, maksim kerendahan hati 1 data, maksim kesepakatan 3 data dan maksim kesimpatian 1 data. Tingkat kesantunan yang agak mendominasi dapat dilihat pada tabel 1 . 
Tabel 1. Penggunaan Unsur Kesantunan Berbahasa oleh Para Paslon Dalam Debat Politik Pilkada DKI Jakarta 2017

\begin{tabular}{|c|c|c|c|c|c|c|c|c|c|c|}
\hline \multicolumn{11}{|c|}{ Unsur Kesantunan } \\
\hline \multicolumn{2}{|c|}{ Jenis Tuturan } & Jml & $\begin{array}{c}\text { Jml } \\
\text { Ttl }\end{array}$ & $\begin{array}{c}\text { Gaya } \\
\text { Bahasa }\end{array}$ & Jml & $\begin{array}{l}\text { Strategi } \\
\text { Bertutur }\end{array}$ & Jml & $\begin{array}{c}\text { Prinsip } \\
\text { Kesantunan }\end{array}$ & $\begin{array}{l}\text { Mm- } \\
\text { tuhi }\end{array}$ & $\begin{array}{l}\text { Me- } \\
\text { lang- }\end{array}$ \\
\hline \multirow{4}{*}{ Ekspresif } & Menyindir & 23 & \multirow{4}{*}{35} & \multirow{4}{*}{ Sarkasme } & \multirow{4}{*}{4} & \multirow{4}{*}{ TerusTerang } & \multirow{4}{*}{31} & \multirow{4}{*}{ Kebijaksanaan } & \multirow{4}{*}{8} & \multirow{4}{*}{-} \\
\hline & Mengkritik & 7 & & & & & & & & \\
\hline & Mengeluh & 1 & & & & & & & & \\
\hline & Mengecam & 4 & & & & & & & & \\
\hline \multirow{7}{*}{ Direktif } & Mempengaruhi & 2 & \multirow{7}{*}{10} & \multirow{7}{*}{ Sinisme } & \multirow{7}{*}{27} & \multirow{7}{*}{ KesantunanNegatif } & \multirow{7}{*}{22} & \multirow{7}{*}{ Kedermawanan } & \multirow{7}{*}{2} & \multirow{7}{*}{8} \\
\hline & Mengajak & 1 & & & & & & & & \\
\hline & Menghimbau & 2 & & & & & & & & \\
\hline & Memaksa & 1 & & & & & & & & \\
\hline & Meyakinkan & 1 & & & & & & & & \\
\hline & Meminta & 2 & & & & & & & & \\
\hline & Menawarkan & 1 & & & & & & & & \\
\hline Komisif & Berjanji & 7 & 7 & Ironi & 55 & Kesantnnan Positif & 17 & Pujian & 1 & 14 \\
\hline Deklaratif & Melarang & 1 & 1 & Antifrasis & - & Samar-samar & 16 & Kerendahan Hati & 1 & 25 \\
\hline \multirow{6}{*}{ Representatif } & Menyatakan & 20 & 33 & \multirow{2}{*}{ Inuendo } & \multirow{2}{*}{-} & - & - & Kesepakatan & 3 & 12 \\
\hline & Melaporkan & 3 & & & & - & & Kesimpatian & 1 & 11 \\
\hline & Membual & 2 & & Satire & - & & & & & \\
\hline & Menyebutkan & 1 & & & & & & & & \\
\hline & Menjelaskan & 1 & & & & - & & & & \\
\hline & Memberitahu & 6 & & - & & & & & & \\
\hline \multicolumn{2}{|c|}{ Total } & 86 & 86 & Total & 86 & Total & 86 & Total 105 & 16 & 70 \\
\hline
\end{tabular}

Sumber : Debat Pasangan Calon Gubernur dan Wakil Gubernur DKI Jakarta dalam Debat Pilkada, 2017

Dalam menyampaikan opininya, jenis tindak tutur yang paling dominan digunakan oleh para politikus adalah ekspresif 33 data dalam bentuk menyindir, mengkritik, mengeluh, dan mengecam. Selanjutnya, menggunakan jenis tindak tutur representatif 33 data dalam bentuk menyatakan, melaporkan, membual, menyebutkan, menjelaskan dan memberitahukan; jenis tindak tutur direktif 10 data dalam bentuk mempengaruhi, mengajak, memhimbau, memaksa, meyakinkan, meminta, dan menawarkan; tindak tutur deklaratif (1data)dalam bentuk melarang:sedangkan komisif 7 data dalam bentuk berjanji. Jenis tindak tutur tersebut,diantaranya terlihat pada contoh berikut ini, yaitu ekspresif 1 , direktif 2, representatif 3, komisif 4, dan deklaratif 5.

\subsection{Penggunaan Jenis Tindak Tutur Para Paslon Dalam Debat Pilkada DKI Jakarta}

Jenis tindak tutur dalam berkomunikasi, yaitu representatif, direktif, ekspresif, komisif, dan deklaratif. Berdasarkan analisis data pada penelitian ini, ternyata jenis tindak tutur yang paling dominan digunakan oleh para paslon adalah ekspresif, kemudian diikuti oleh jenis tindak tutur yang lain sebagaimana disajikan berikut ini.

1. Ekspresif

Penggunaan tindak tutur ekspresif dalam debat paslon pilkada DKI Jakarta 2017 oleh para paslon ditemukan sejumlah 33 tuturan yang tersebar dalam beberapa bentuk, yaitu data 1 mengeluh, 2-3 mengkritik, dan 4-5 menyindir salah satu contohnya berikut ini.

1) Tentu saya juga memaklumi selama 4 tahun lebih ini, banyak warga Jakarta hanya melihat penampilan saya. Terlalu menggebu-gebu, terlalu semangat. Akibatnya visi-misi yang sudah kami capai, program yang sudah terukur, hilang. Sebagian melihat saya terlalu temperamental" (D1P2-1)

2) "Jadi kami tidak setuju melakukan bantuan langsung tunai. Karena itu tidak mendidik (D1P215).

3) "Sekarang bagaimana caranya menciptakan 200 ribu pengusaha-pengusaha baru dan membutuhkan biaya yang sangat besar. Karena berdasarkan studi mengatakan bahwa binaan itu hanya $10 \%$ yang berhasil (D1P2-17).

4) "Saya melihat ada ketidak berpihakan, pada sistem sekarang. Dimana yang kaya makin kaya, yang miskin makin miskin. Yang usaha besar makin besar, yang usaha kecil makin terpuruk" (D1P3-16).

5) "Kedua, tidak hanya dengan berikan iming-iming tunjangan kinerja. Itu baik, karena berikan stick. Tapi budaya, pemimpin harus mendukung bukan memukul, harus memotivasi" (D2P3-4). 
Pada tuturan pertama terlihat penutur menggunakan jenis tindak tutur ekspresif mengeluh. Hal itu disebabkan, terlihat penutur mengutarakan keluhannya dengan mengatakan bahwa orang-orang atau pihak-pihak yang dimaksud hanya melihat penampilan luarnya saja, sedangkan kinerjanya selama ini tidak dianggap berarti bagi orang-orang tersebut. Hal itu, terlihat pada penggunaan kalimat banyak warga Jakarta hanya melihat penampilan saya, program yang sudah terukur, hilang, dan sebagian melihat saya terlalu temperamental. Jadi, dari tiga penggunaan kalimat tersebut, sangat terlihat jelas penutur mengeluh terhadap orang-orang yang hanya memandangnya dari luar saja.

Selanjutnya, pada tuturan kedua dan ketiga terdapat pemanfaatan jenis tindak tutur ekspresif mengkritik. Pada tuturan kedua, terlihat penutur mengkritik pihak dimaksud dengan mengatakan bahwa pemimpin yang memberikan bantuan lewat bantuan langsung tunai itu tidak mendidik. Hal itu terlihat pada penggunaan kalimat kami tidak setuju melakukan bantuan langsung tunai. Karena itu tidak mendidik. Begitu juga halnya, pada tuturan ketiga juga terlihat penutur mengkritik pihak yang dimaksud dengan cara menyatakan bahwa adanya rancangan program yang tidak berhasil dilakukan oleh pihak yang dimaksud tersebut. Program itu adalah menciptakan 200 ribu pengusaha-pengusaha baru.

Selain itu, pada tuturan keempat juga terlihat penutur menggunakan jenis tindak tutur ekspresif menyindir dalam mengemukakan pendapatnya. Hal itu terlihat pada tuturannya mengatakan bahwa adanya ketidakberpihakan sistem atau adanya ketidakadilan sistem yang terjadi, sehingga orang yang kaya akan semakin kaya dan orang yang miskin akan semakin miskin. Dengan menggunakan kata-kata ketidakberpihakan, pada sistem sekarang, maka secara langsung penutur mengatakan bahwa sistem kepemimpinan saat ini tidak baik atau timpang. Begitu juga halnya, pada tuturan kelima terlihat penutur menggunakan jenis tindak tutur menyindir. Hal itu terlihat pada penggunaan kalimat pemimpin harus mendukung bukan memukul, harus memotivasi. Kalimat tersebut, bermaksud untuk menyindir pihak yang dimaksud dengan mengatakan bahwa jika menjadi seorang pemimpin itu seharusnya saling mendukung, kerja sama bukan sebaliknya.

2. Direktif

Penggunaan tindak tutur direktif debat paslon pilkada DKI Jakarta 2017 oleh para paslon ditemukan 10 tuturan bentuk meyakini, mengajak, meminta, dan memaksa, berikut salah satu bagian analisis dari tuturan dalam bentuk direktif salah satu contohnya berikut ini.

1) Kami berkeliling bergerilya ke lapangan Menemui masyarakat yang makan sehari-hari pun masih sulit. Yang kedua, kami ingin juga meyakinkan bahwa tidak hanya mereka diberikan bantuan sementara secara ekonomi, secara makro kita ingin meningkatkan pertumbuhan (D1P1-12).

2) Jakarta bukan tempat ujicoba. Kami menempatkan Jakarta sebagai tempat untuk kita mengabdi, mengajak maju bersama dan Insya Allah tempat berpahala bagi semua (D1P3-2).

3) Kami butuhkan 5 tahun lagi, kita akan tunjukkan bahwa anak-anak DKI bisa unggul sampai perguruan tinggi dengan beasiswa" (D2P2-4).

4) Izinkan kami untuk tuntaskan yang sudah kami awali. Mohon doa restu dan jangan takut untuk memilih sesuai hati (D2P2-1).

5) Jadi, kita harus melihat gep yang berhasil kami turunkan begitu luar biasa. Orang bertanya kok bisa diturunkan? Padahal orang miskin Jakarta selalu ada sama kita. Orang dari luar kota akan tetap datang tetap terhitung miskin (D1P2-10).

Tuturan pertama merupakan tuturan direktif meyakini. Hal itu disebabkan penutur dengan langsung menggunakan kata meyakini untuk meyakinkan masyarakat agar percaya bahwa bukan hanya akan memberikan batuan secara ekonomi saja. Akan tetapi, penutur juga meyakinkan bahwa dia akan memberikan bantuan secara makro sehingga nantinya akan dapat meningkatkan pertumbuhan ekonomi. Dari paslon tiga untuk mengabdi dan bekerja sama dengan tujuan untuk melihat permasalahan yang ada di Jakarta dan merubah kearah yang lebih baik. Selanjutnya, pada tuturan kedua merupakan tuturan direktif mengajak. Hal itu disebabkan, penutur terlihat menggunakan kata-kata mengajak dengan tujuan agar pihak yang dimaksud mau untuk menempatkan Jakarta sebagai tempat mengabdi bersama demi kemajuan Jakarta. Hal itu terlihat pada penggunaan kalimat kami menempatkan Jakarta sebagai tempat untuk kita mengabdi, mengajak maju bersama.

Selain itu, pada tuturan ketiga juga terlihat penutur menggunakan jenis tindak tutur direktif meminta. Penggunaan klausa Kami butuhkan 5 tahun lagi bermaksud meminta agar pihak yang dimaksud mau memberikan waktu 5 tahun untuk dapat menunjukkan bentuk pelayanan publik yang penutur tawarkan kepada masyarakat. Pelayanan publik tersebut, yaitu pelayanan untuk anak-anak DKI yang dipastikan bisa unggul sampai perguruan tinggi. Begitu juga halnya, pada tuturan keempat juga merupakan tuturan yang menggunakan jenis tuturan direktif meminta. Hal itu terlihat pada tuturan penutur yang menggunakan kata-kata izinkan kam dan mohon doa restu. Kata-kata tersebut, bermaksud untuk meminta izin dan doa restu kepada masyarakat untuk menuntaskan program yang sudah dikerjakan dan jangan takut memilih Paslon saat Pemilu.

Terakhir, pada tuturan kelima juga merupakan jenis tindak tutur direktif memaksa. Hal itu disebabkan, penutur menggunakan kata-kata harus bermaksud memaksa pihak dimaksud untuk harus melihat gep 
yang berhasil penutur turunkan. Hal itu terlihat pada kalimat Jadi, kita harus melihat gep yang berhasil kami turunkan begitu luar biasa.

3. Representatif

Penggunaan tindak tutur representatif debat paslon pilkada DKI Jakarta 2017 oleh para paslon ditemukan 33 tuturan baik dalam bentuk menyebutkan, membual, memberitahukan ,menjelaskan, dan melaporkan berikut salah satu bagian analisis dari tuturan representatif salah satu contohnya berikut ini.

1) Selain yang sudah baik, potret Jakarta hari ini, ketimpangan meningkat, daya beli sebagian masyarakat menurun,disamping itu kualitas hidup masyarakat menurun akibat banjir, macet, sampah yang tidak bisa terselesaikan dengan baik (D1P1-1).

2) Kami punya program OK-OC. OK-OC. One Kecamatan, One Centre for Entrereneurship. Di mana pola pikirnya ke depan kita akan permudah lahan usaha dengan garasi inovasi. Kita pemudah juga kredit sampai 300 juta rupiah (D1P3-8)

3) Harga beras menurut laporan Bank Indonesia, paling stabil lima tahun terakhir. Karena kami memanfaatkan BUMD yang memang bekerja dengan baik (D1P2-13)

4) Ketika kita bicara pelayanan publik, pada 2013, kami keluarkan badan layanan terpadu satu pintu Kenapa badan pelayanan, bukan perizinan? Perizinan itu warga datang kepada kami, memberi izin atau tidak. Kalau pelayanan, wargalah atasan kami. Kami melayani. Ini adalah dasar pelayanan publik. Kami jadi pelayan yang miliki hasrat empati untuk layani masyarakat (D2P2-6)

5) Saya mendapat kehormatan bersama-sama Mas Anies dalam kurun waktu 12 bulan terakhir berkeliling menjelajah ke 44 kecamatan, 267 kelurahan di wilayah Jakarta. Saya melihat ada 3 tema yang secara konsisten diangkat oleh warga sebagai aspirasi mereka (D1P3-7).

Tuturan pertama terdapat pemanfaatan jenis tindak tutur representatif menyebutkan. Hal itu terlihat, pada tuturan yang disampaikan penutur untuk mengungkapkan rasa tidak senangnya terhadap kinerja pemerintah dalam penataan kota. Dengan cara menyebutkan hal-hal mengenai potret Jakarta saat ini. Hal-hal tersebut berupa meningkatnya ketimpangan, daya beli sebagian masyarakat menurun. Selain itu, penutur juga menyebutkan penyebab turunnya kualitas hidup masyarakat, yaitu akibat banjir, macet, sampah. Jadi, dapat disimpulkan bahwa dengan jelas penutur menggunakan jenis tindak tutur menyebutkan dalam mengungkapkan pendapatnya.

Selanjutnya, tuturan kedua merupakan jenis tindak tutur representatif membual. Hal itu terlihat pada penggunaan kalimat OK-OC. OK-OC. One Kecamatan, One Centre for Entrepreneurship.
Tuturan tersebut, disampaikan wakil paslon tiga dengan mengatakan bahwa akan membuat program yang dapat membantu masyarakat. Hal tersebut, bertujuan untuk memberikan pengaruh kepada masyarakat untuk memilihnya. Akan tetapi, apa yang disampaikan belum dapat dibuktikan kebenarannya, sehingga tuturan tersebut dikategorikan masih membual. Pada tuturan ketiga, juga terlihat penutur menggunakan jenis tindak tutur representatif tetapi yang bagian memberitahu. Hal tersebut, disebabkan penutur telihat memberitahu bahwa harga beras menurut laporan Bank Indonesia paling stabil lima tahun terakhir seperti dalam harga beras menurut laporan Bank Indonesia.

Pada tuturan keempat, terlihat jelas penutur menggunakan jenis tindak tutur representatif menjelaskan. Hal yang dijelaskan penutur dalam tuturannya adalah penjelasan tentang kenapa dia mengeluarkan badan pelayanan dan bukan perizinan. Berdasarkan tuturannya, penutur menjelaskan bahwa perizinan itu warga yang datang pemerintah, sedangkan pelayanan itu pemerintah yang datang ke warga. Jadi, dengan jelas penutur menjelaskan pemerintahlah yang seharusnya melayani publik. Selanjutnya, pada tuturan kelima terlihat penutur menggunakan jenis tindak tutur representatif melaporkan. Hal itu terlihat dalam tuturan bahwa penutur melaporkan dirinya dan mas Anies bahwa dalam kurun waktu 12 bulan terakhir sudah pergi berkeliling menjelajah ke 44 kecamatan, 267 kelurahan di wilayah jakarta. Hal itu terlihat pada penggunaan kalimat yang dicetak tebal pada tuturan tersebut.

4. Komisif

Penggunaan tindak tutur komisif debat paslon pilkada DKI Jakarta 2017 oleh para paslon ditemukan 3 tuturan dalam bentuk berjanji. Berikut salah satu bagian analisis dari tuturan dalam bentuk komisif salah satu contohnya berikut ini.

1) Insya Allah, jika saya dan Mpok Sylvi terpilih menjadi Gubernur dan Wakil Gubernur Jakarta, kami berdua akan menjaga integritas kami (D1P1-9).

2) Jakarta punyai 135.222 pegawai PNS dan NonPNS. Kami akan pastikan mereka bekerja maksimal layani warga dengan hati(D2P2-5).

3) Kami akan hadirkan kota yang maju, bahagia, aman, damai, dan bebas dari segala macam kriminalitas (D1P3-6).

Tuturan pertama, terdapat penggunaan jenis tindak tutur komisif berjanji. Hal itu terlihat pada penggunaan kalimat kami berdua akan menjaga integritas kami. artinya, penutur menjanjikan akan menjaga integritas jika masyarakat memilihnya menjadi pemimpin. Begitu juga halnya pada tuturan kedua juga merupakan jenis tindak tutur komisif berjanji atau lebih tepatnya menjanjikan. Hal yang 
dijanjikan penutur dalam tuturannya adalah akan memastikan PNS dan Non-PNS akan berkerja maksimal dalam melayani warga sepenuh hati. Hal itu terlihat pada penggunaan kalimat kami akan pastikan mereka bekerja maksimal layani warga dengan hati. Hal yang menekankan pada jenis tindak tutur komisif menjanjikan adalah pada kata kami akan pastikan.

Begitu juga halnya tuturan ketiga, juga merupakan jenis tindak tutur komisif berjanji. Hal yang dijanjikan penutur dalam memajukan kota dengan bahagia, aman, damai dan bebas terdapat pada kata kami akan hadirkan. Hal yang menekankan pada jenis tindak tutur komisif menjanjikan adalah pada kata akan menghadirkan.

5. Deklaratif

Penggunaan tindak tutur deklaratif debat paslon pilkada DKI Jakarta 2017 oleh para paslon ditemukan pertama tuturan dalam bentuk melarang berikut salah satu bagian analisis dari tuturan dalam bentuk deklaratif salah satu contohnya berikut ini.

Kalau ada ibu-ibu datang membawa masalah KJP (Kartu Jakarta Pintar), janganlah kirimkan kata-kata yang tak patut, tapi itu terjadi pada kasus ini (D3P2$1)$.

Tuturan pertama merupakan jenis tindak tutur deklaratif menjanjikan dengan menggunakan kalimat janganlah kirimkan kata-kata yang tak patut, tapi itu terjadi pada kasus ini. Hal tersebut bertujuan untuk melarang pihak-pihak yang dimaksud mengatakan kata-kata yang tidak patut atau tidak layak.

\subsection{Penggunaan Majas Para Paslon Dalam Debat Pilkada DKI Jakarta}

Gaya bahasa yang terdapat dalam tuturan para paslon dalam debat pilkada DKI Jakarta 2017, yaitu ironi, sinisme dan sarkasme.

1. Ironi

Penggunaan gaya bahasa ironi dalam debat paslon pilkada DKI Jakarta 2017 para paslon ditemukan tuturan berjumlah 55 salah satu contohnya berikut ini.

1) "Saya akan berdiri yang terdepan bersama seluruh warga Jakarta untuk mengubah warga ibukota menjadi semakin modern, unggul, tetapi tetap menjadi kota yang manusiawi dan selalu berjati diri, berkarakter pada Jakarta dan Indonesia yang kita cintai" (D1P1-5).

2) "Jadi saya hanya ingin bertanya Pak, itu kan tentu documenter yang menggambarkan derita dan nestapa dari warga Jakarta. Rakyat kecil yang hidupnya sudah sangat sulit dan akhirnya tergusur ke tempat lain. Bapak punya alasan tentunya mengapa menggusur, tetapi bagaimana perasaan bapak sebagai pemimpin sekaligus pengambil kebijakan tersebut melihat warga yang hidupnya semakin sulit begitu semakin sulit? Dan akhirnya kehilangan segalanya" (D4P31-1)
3) "Kami bukan memerangi kemiskinan. Pendiri republik ini tidak pernah mengatakan memerangi kemiskinan. Mereka mengatakan memajukan kesejahteraan umum. Mereka mengatakan mencerdaskan kehidupan bangsa. Mereka tidak mengatakan memerangi kebodohan" (D1P3-13).

4) Ketika kita bicara pelayanan publik, pada 2013, kami keluarkan badan layanan terpadu satu pintu Kenapa badan pelayanan, bukan perizinan? Perizinan itu warga datang kepada kami, memberi izin atau tidak. Kalau pelayanan, wargalah atasan kami. Kami melayani. Ini adalah dasar pelayanan publik. Kami jadi pelayan yang miliki hasrat empati untuk layani masyarakat (D2P2-6)

5) Kami seperti orang tua, yang mendidik anak yang rajin harus kerja, yang tidak rajin tidak boleh dapat (D1P2-16).

Tuturan pertama merupakan tuturan yang menggunakan majas ironi. Hal itu terlihat pada tuturan penutur yang bermaksud menyindir secara halus. Hal yang disindir penutur adalah tentang keadaan Jakarta saat ini yang dianggap belum dapat menjadi kota Jakarta yang manusiawi, berjati diri, dan berkarakter. Jadi, secara tidak langsung penutur menyindir lawan tuturnya yang belum bisa menjadikan kota Jakarta seperti yang disebutkan penutur tersebut. Begitu juga halnya, pada tuturan kedua juga terlihat penutur menggunakan majas ironi dalam mengungkapkan pendapatnya. Hal itu terlihat pada penggunaan kata kiasan yang bermaksud untuk menutupi maksud sebenarnya, seperti dalam kalimat itu kan tentu dokumenter yang menggambarkan derita dan nestapa dari warga Jakarta. Kalimat tersebut, bertujuan untuk menyindir dengan mengaitkan masalah lama di Jakarta, secara tidak langsung ungkapan yang disampaikan menyinggung paslon dua karena terkait ada masalah yang belum terselesaikan yang pada saat itu paslon dua masih menjabat menjadi gubernur.

Selanjutnya, pada tuturan ketiga juga terlihat pemanfaatan majas ironi. Hal itu disebabkan penutur menggunakan kalimat pendiri republik ini tidak pernah mengatakan memerangi kemiskinan. Artinya, secara tidak langsung penutur menyindir calon pemimpin atau pendiri republik yang tidak pernah mengatakan memerangi kemiskinan dan mereka kebodohan. Karena seharusnya, menurut penutur seorang calon pemimpin itu harus mengatakan hal tersebut, bukan mengatakan memajukan kesejahteraan umum dan mencerdaskan kebodohan. Pada tuturan keempat, juga terlihat penutur menggunakan majas bahasa ironi. Hal itu terlihat pada penggunaan kalimat. Ini adalah dasar pelayanan publik. Kami jadi pelayan yang miliki hasrat empati untuk layani masyarakat. Kalimat tersebut, bermaksud untuk menyindir pihak yang dimaksud dengan mengatakan bahwa ketika dia menjadi pemimpin itu harusnya melayani masyarakat 
seperti pemimpinlah yang datang ke warga bukan sebaliknya. Begitu juga halnya, pada tuturan kelima juga terlihat penutur menggunakan gaya bahasa ironi untuk menyindir pihak yang dimaksud. Hal itu terlihat pada penggunaan kalimat yang mengibaratkan seorang seperti orang tua yang mendidik anaknya. Maksud sebenarnya dari kalimat tersebut adalah untuk menyindir masyarakat yang tidak giat dalam bekerja.

2. Sinisme

Penggunaan gaya bahasa sinisme dalam debat paslon pilkada DKI Jakarta 2017 salah satu contohnya berikut ini.

1) "Tentunya meningkatkan kualitas lingkungan hidup dengan cara solusi yang efektif untuk mengatasi problem yang akut seperti banjir, sampah, dan polusi. Dan terakhir, dan tidak kalah penting adalah meyakinkan hadirnya rasa aman dan adil untuk seluruh warga Jakarta" (D1P1-4)

2) "Tentu saya juga memaklumi selama 4 tahun lebih ini, banyak warga Jakarta hanya melihat penampilan saya. Terlalu menggebu-gebu, terlalu semangat. Akibatnya visi-misi yang sudah kami capai, program yang sudah terukur, hilang. Sebagian melihat saya terlalu temperamental" (D1P2-1)

3) "Pertama aparatur pemerintah yang tidak kompeten butuhkan lebih dari sekedar good governance, itu pendekatan era 90an. Sekarang eranya open governance di mana pemerintah dan masyarakat membangun bekerja bersama-sama" (D2P3-3)

Tuturan pertama terlihat penutur menggunakan majas sinisme untuk menyindir permasalahan banjir dan keamanan di Jakarta. Penutur menyindir pihak yang dimaksud dengan mengatakan bahwa program yang dijalankan paslon dua dalam persoalan kualitas lingkungan hidup belum teratasi dengan baik karena masih seringnya banjir, sampah, dan polusi. Jadi, secara tidak langsung penutur sudah mencela kualitas kerja pihak yang dimaksud (paslon dua), sehingga dapat menyinggung perasaan pihak yang dimaksud tersebut. Begitu juga halnya, pada tuturan kedua juga merupakan tuturan yang menggunakan majas sinisme. Hal itu disebabkan penutur terlihat mengkritik pihak-pihak yang dimaksud hanya melihat dirinya dari luar saja yang terlihat temperamental, namun visi-misi yang sudah tercapai tidak dianggap atau dianggap hilang saja. Kritikan tersebut terlihat dalam penggunaan kalimat banyak warga Jakarta hanya melihat penampilan sayadan program yang sudah terukur, hilang.

Selanjutnya, pada tuturan ketiga, terdapat pemanfaatan majas sinisme. Hal itu terlihat pada penggunaan kalimat lebih dari sekedargood govermance, itu pendekatan era 90andansekarang eranya open govermance. Maksudnya penutur ingin mengkritik pemerintah yang masih menggunakan cara lama dalam memimpin. Penutur menyampaikan bahwa sekarang ini, pemerintah harusnya menggunakan pendekatan open govermance yaitu dimana masyarakat dan pemerintah bekerja sama, bukan lagi dengan pendekatan open govermance yaitu bentuk pemerintahan yang tidak begitu menampakkan kerja sama dengan masyarakat atau tidak open.

3. Sarkasme

Penggunaan gaya bahasa sarkasme dalam debat paslon pilkada DKI Jakarta 2017 para paslon ditemukan tuturan berjumlah 4 salah satu contohnya berikut ini.

1) "Kami bukan bicara soal keadilan sosial saja, kami adalah orang yang telah melawan ketidakadilan. Ketika oknum-oknum PNS mengingkari sumpah jabatan, menekan, mempersulit, kami lawan semua, kami singkirkan.” (D2P2-1)

2) "Tadi, kan, bilang ada jutaan anak milenial yang butuh rumah, terus (katanya) rakyat mau jual rumah. Saya anggap orang mau jual rumah nih, bapak-ibu mau jual rumah Rp300 juta, ini enggak usah bunga, ini (uang muka) sama pemerintah. Kalau (harga rumah) Rp350 juta kali satu juta rumah (sama dengan) Rp350 triliun. Itu uang dari mana? Ngomong gampang: banyak yang mau jual rumah, tapi enggak ada duit buat beli." (D3P2-2)

3) "Kepemimpinan itu (harusnya) datang dengan pesan-pesan yang membuat warga merasa tenang. Yang sekarang terjadi tidak (begitu). Orang kemudian jadi berdebat sesuatu yang enggak perlu diperdebatkan, tetapi kenapa terjadi? Karena pemimpinnya provokatif." (D3P3-6)

4) "Saya selalu dituduh. tuduhan-tuduhan itu disampaikan oleh lawan politik karena mereka tidak memiliki program yang jelas." (D3P2-6)

Pada tuturan pertama, terlihat pemanfaatan majas sarkasme. Penggunaan frasa "kami singkirkan "dirasa kasar jika disebutkan di ruang publik apalagi pada debat yang disiarkan secara langsung oleh beberapa televisi nasional. Makna yang tertangkap dari tuturan tersebut adalah penutur sangat tegas dalam memberantas oknum yang tidak bertanggung jawab dalam menegakkan keadilan. Dengan demikian, tuturan ini dapat digolongkan ke dalam majas sarkasme. Selanjutnya, tuturan kedua juga menggunakan majas sarkasme. Hal itu terlihat dari kalimat "Itu uang dari mana? Ngomong gampang: banyak yang mau jual rumah, tapi enggak ada duit buat beli." Jika dikaitkan dengan konteks, pernyataan tersebut disampaikan oleh paslon dua ketika menanggapi program perumahan dengan dp rendah yang diusung paslon lain. Pernyataan tersebut dimaknai kasar karena akan menyakiti hati lawan tutur atau pendengar tuturannya. Selain itu, dari pernyataan tersebut juga akan mengecilkan hati 
masyarakat yang sangat menginginkan rumah dengan harga murah.

Berikutnya, penggunaan majas sarkasme terdapat pada tuturan ketiga. Tuturan tersebut disampaikan oleh paslon tiga yang secara langsung menyindir paslon petahana. Hal itu terlihat dari frasa "karena kepemimpinannya provokatif" yang ditujukan untuk paslon dua. Maksud yang tertangkap dari pernyataan tersebut berkaitan dengan cara pemerintah yang sedang menjabat dalam memimpin Jakarta, memberi isu-isu negatif sehingga mengubah sudut pandang masyarakat. Namun, hal itu merupakan pendapat dari paslon tiga terhadap paslon dua. Selanjutnya, menggunakan majas sarkasme melalui semua kalimat dalam tuturan keempat. Tuturan tersebut disampaikan oleh paslon dua ketika membantah isu SARA yang ditanyakan kepadanya. Makna dari tuturan yaitu memberikan sindiran keras kepada paslon lain dan menganggap tuduhan-tuduhan itu dapat menjatuhkan muka dirinya. Tidak hanya itu, penutur juga menyatakan bahwa ia dituduh oleh paslon-paslon lain tidak punya program yang jelas.

\subsection{Penggunaan Strategi Bertutur Para Paslon dalam Debat Pilkada DKI Jakarta}

Strategi bertutur menjadi lima dengan tujuan untuk mengurangi kekecewaan petutur (mitra tutur) atas tindakan yang dilakukan oleh penutur yaitu: strategi terus terang tanpa basa-basi, strategi kesantunan positif, strategi kesantunan negatif, dan strategi bertutur samarsamar. Setiap strategi bertutur ini dapat dijelaskan sebagai berikut.

1. Terus Terang tanpa Basa-Basi

Berdasarkan identifikasi dan klasifikasi data, ditemukan 31 tuturan penggunaan strategi bertutur terus terang tanpa basa-basi (TTTBB) dalam debat paslon pilkada DKI Jakarta 2017 salah satu contohnya berikut ini.

1) "Tentunya meningkatkan kualitas lingkungan hidup dengan cara solusi yang efektif untuk mengatasi problem yang akut seperti banjir, sampah, dan polusi. Dan terakhir, dan tidak kalah penting adalah meyakinkan hadirnya rasa aman dan adil untuk seluruh warga Jakarta." (D1P1-4)

2) "Tentu saya juga memaklumi selama 4 tahun lebih ini, banyak warga Jakarta hanya melihat penampilan saya. Terlalu menggebu-gebu, terlalu semangat. Akibatnya visi-misi yang sudah kami capai, program yang sudah terukur, hilang. Sebagian melihat saya terlalu temperamental." (D1P2-1)

3) "Kami bukan bicara soal keadilan sosial saja, kami adalah orang yang telah melawan ketidakadilan. Ketika oknum-oknum PNS mengingkari sumpah jabatan, menekan, mempersulit, kami lawan semua, kami singkirkan.” (D2P2-1)
4) "Tapi sebelum saya sampai situ, sebenarnya kalau petahana itu (harusnya) menunjukkan karya, bukan meluncurkan program. Kalau meluncurkan program saat kampanye, itu adalah calon. Tapi kalau petahana, tunjukkan yang sudah dikerjakan.” (D3P3-1)

5) "Kami mengurangi $2 / 3$ lokasi banjir yang dulu di Sunter. Saya dateng itu tiga minggu tenggelam. Sekarang hanya berjam-jam saja, karena sudah kami kerjakan. Jadi kami bukan melakukan fisik untuk menyingkirkan orang justru orang-orang banyak saya temui bersyukur. (D4P2-2)

Pada tuturan pertama, terdapat strategi terus terang tanpa basa-basi, terlihat dari cara penutur menyampaikan pendapatnya secara langsung dengan solusi-solusi yang akan diberikan atas permasalahan yang terjadi di Jakarta. Jika dikaitkan dengan konteksnya, penutur merupakan paslon satu yang sedang menjelaskan visi misi yang akan dibangun ke depan jika ia dipilih menjadi gubernur. Selanjutnya, tuturan kedua juga memanfaatkan strategi terus terang tanpa basa-basi. Makna yang tertangkap pada tuturan tersebut adalah penutur mengungkapkan secara jelas pandangan-pandangan masyarakat terhadap dirinya selama menjabat sebagai gubernur. Ia juga menyatakan bahwa sebagian masyarakat hanya melihatnya dari penampilan luar saja melalui frasa "sebagian melihat saya terlalu temperamental".

Pemanfaatan strategi bertutur terus terang tanpa basabasi juga pada tuturan ketiga, penutur dengan tegas menjelaskan bahwa mereka (cagub dan cawagub) bukan sekedar berwacana dalam menegakkan keadilan, namun secara langsung bertindak. Konteks tuturan tersebut adalah paslon dua menanggapi pertanyaan moderator tentang komitmen yang akan dibangun jika terpilih menjadi gubernur dan wakil gubernur kembali. Tuturan tersebut juga secara langsung menegaskan bahwa mereka bersungguhsungguh dalam melawan ketidakadilan. Ungkapan tersebut ditunjukkan dengan frasa "kami singkirkan" diakhir tuturan.

Selanjutnya, tuturan keempat juga menggunakan strategi terus terang tanpa basa-basi. Hal ini dapat ditunjukkan dengan frasa "...sebenarnya kalau petahana itu (harusnya) menunjukkan karya, bukan meluncurkan program." Dari tuturan tersebut, terlihat penutur menyampaikan pendapatnya dengan menunjuk langsung pihak yang ingin dijatuhkannya. Jika dikaitkan dengan konteksnya, penutur yang merupakan paslon tiga, menanggapi pertanyaan moderator terkait Kartu Jakarta Lansia yang diusung oleh lawan kandidatnya, yaitu paslon dua. Menurut penutur, seharusnya paslon petahana itu memunculkan karya yang telah dikerjakan, bukan memunculkan program-program baru seperti calon lainnya. 
Terakhir, pada tuturan kelima, penggunaan strategi bertutur terus terang tanpa basa-basi terlihat semua tuturan. Jika dikaitkan dengan konteks, penutur menanggapi pertanyaan kandidat lain terkait masalah banjir di Jakarta. Penutur yang merupakan cagub petahana ini menjelaskan apa yang telah ia lakukan untuk mengatasi banjir di Jakarta menjadi lebih baik. Penutur juga membantah tuduhan bahwasanya banyak orang yang mengeluh, melainkan yang ditemuinya adalah banyak orang yang bersyukur.

2. Terus Terang Kesantunan Negatif

Strategi bertutur terus terang dengan basa-basi kesantunan negatif (TTKN) ditemukan 22 tuturan. Strategi ini digunakan penutur agar sesuatu yang ada dalam dirinya dinilai baik atau positif. Dalam debat paslon pilkada DKI Jakarta 2017, strategi ini digunakan agar dirinya dinilai baik namun bisa juga untuk menyindir kandidat lain. Salah satu contohnya berikut ini..

1) "Supaya kalau kami dilanjutkan lagi bukan hanya visi-misi program tercapai tapi Ahok-nya sudah mencari iCore7, i7, bukan pentium lagi kalau komputer. Sehingga kami akan lebih baik, kesalahpahaman ini akan bisa dihindari." (D1P23)

2) "Saya mendapat kehormatan bersama-sama Mas Anies dalam kurun waktu 12 bulan terakhir berkeliling menjelajah ke 44 kecamatan, 267 kelurahan di wilayah Jakarta. Saya melihat ada 3 tema yang secara konsisten diangkat oleh warga sebagai aspirasi mereka." (D1P3-7)

3) "Izinkan kami untuk tuntaskan yang sudah kami awali. Mohon doa restu dan jangan takut untuk memilih sesuai hati."'(D2P3-1)

4) "Kami berdua bawa pengalaman, pengetahuan, jaringan. Ketika kita bicara hadirkan rasa aman, motivasi bekerja, reformasi birokrasi akan berjalan cepat dengan suasana kerja yang positif yang buat orang mau berkarya." (D2P3-12)

5) "Sekarang bagaimana logikanya, kalau sampe moratorium mobil mewah tidak boleh masuk? Justru kalau seperti ini yang terjadi adalah mobilmobil murah yang ramah lingkungan yang akan masuk dan Jakarta akan macet. Ya. Apakah solusi seperti ini memang bisa memecahkan persoalan kemacetan di Jakarta?" (D4P2-4)

Pada tuturan pertama, penutur mengungkapkan bahwa jika dirinya terpilih lagi sebagai gubernur, maka ia akan bekerja semakin baik dari sebelumnya. Hal ini ditandai dengan pemilihan frasa “...bukan hanya visi-misi program tercapai tapi Ahok-nya sudah mencari iCore7, i7, bukan pentium lagi kalau komputer." Dari tuturan tersebut dapat disimpulkan bahwa penutur lebih menyelamatkan muka dirinya sendiri dengan menyebutkan kelebihan yang akan diberikannya jika ia terpilih nanti sebagai gubernur. Selanjutnya, untuk tuturan kedua, strategi basa-basi kesantunan negatif diungkapkan secara tersirat melalui makna tuturan tersebut. Jika dikaitkan dengan konteksnya, penutur menanggapi pertanyaan moderator terkait program kerja unggulan untuk meyakinkan calon pemilih. Dapat disimpulkan bahwa apa yang disampaikan oleh penutur mengandung makna lain untuk menimbulkan rasa simpatik bagi calon pemilih.

Dalam tuturan ketiga, strategi bertutur basa-basi kesantunan negatif dapat ditunjukkan dengan kalimat "izinkan kami untuk tuntaskan yang sudah kami awali." Dari pernyataan tersebut, tersirat bahwa penutur menginginkan calon pemilih memilih kembali dirinya untuk memimpin Jakarta agar dapat meneruskan apa yang telah ia kerjakan selama ini. Selain itu, pernyataan itu juga dapat dimaknai sebagai sindiran halus bagi kandidat lain yang akan mencalonkan diri sebagai gubernur dan calon gubernur. Dengan demikian, tuturan ini merupakan pernyataan ini dapat digolongkan sebagai strategi bertutur basa-basi kesantunan negatif. Berikutnya, strategi bertutur basa-basi kesantunan negatif juga digunakan dalam tuturan keempat. Tuturan ini disampaikan oleh paslon tiga ketika menjelaskan komitmen mereka dalam melayani warga selama 5 tahun ke depan. Dari ungkapan tersebut, terlihat bahwa penutur menyatakan kelebihannya dibanding kandidat lain melalui kalimat "kami berdua bawa pengalaman, pengetahuan, jaringan." Dapat disimpulkan bahwa tuturan tersebut bertujuan agar calon pemilih mengetahui kelebihan yang dimiliki oleh penutur. Terakhir, tuturan kelima dapat dipahami sebagai pertanyaan yang menyudutkan salah satu paslon dan penyelamatan muka dirinya. Tuturan ini disampaikan oleh paslon dua yang mengajukan pertanyaan terkait program baru untuk mengatasi kemacetan di Jakarta yang akan dimunculkan oleh paslon lain. Dari tuturan tersebut, penutur memaparkan hal-hal yang akan terjadi jika program tersebut dilakukan, seperti kemacetan yang akan bertambah, dll.. Dengan demikian, tersirat penutur berpendapat bahwa program tersebut bukanlah solusi, melainkan masalah baru.

3. Terus Terang Kesantunan Positif (TTKP)

Berdasarkan identifikasi dan klasifikasi data, ditemukan 17 tuturan penggunaan strategi bertutur terus terang dengan basa-basi kesantunan positif (TTKP) dalam debat paslon pilkada DKI Jakarta 2017 salah satu contohnya berikut ini.

1) "Visi saya lima tahun ke depan adalah menjadikan Jakarta semakin maju, aman, adil, dan sejahtera. Untuk dapat mewujudkan itu semua, komitmen saya dan tentunya misi saya adalah, untuk mengatasi semua permasalahan di Jakarta, meningkatkan pembangunan sehingga Jakarta semakin maju ke depan.” (D1P1-3)

2) "Saya juga bersyukur, sebagian orang Jakarta melihat hasil nyata. Sungai lebih bersih. Semua kelihatan. Pelayanan lebih baik. Terutama, 
misalnya saya beri contoh, saya bersyukur punya Mas Djarot, yang melihat apa yang telah saya kerjakan dan saya juga belajar terus dari Mas Djarot. Namanya juga Djarot Saiful Hidayat. Supaya saya agak-agak mirip dengan beliau." (D1P2-2)

3) "Ketika kita bicara pelayanan publik, pada 2013, kami keluarkan badan layanan terpadu satu pintu. Kenapa badan pelayanan, bukan perizinan? Perizinan itu warga datang kepada kami, memberi izin atau tidak. Kalau pelayanan, wargalah atasan kami. Kami melayani. Ini adalah dasar pelayanan publik. Kami jadi pelayan yang miliki hasrat empati untuk layani masyarakat." (D2P2-6)

4) "Reklamasi tetap akan dilanjutkan dengan mempertimbangkan kepentingan masyarakat nelayan. Pertimbangan lainnya adalah reklamasi akan bisa menyerap 15 persen tenaga kerja." (D3P2-5)

5) "Jadi kalau ada tim sukses saya yang mengatakan, nggak papa nggak santun, yang penting jujur. Salah, saya bilang. Atau ya buat apa, jujur atau kelihatan santun, tapi nggak jujur. Salah. Yang paling ideal ya kita harus berintegritas dengan rekam jejak yang baik, dan kita juga santun sebagai pejabat publik, makanya saya beruntung ada Mas Saiful Djarot Hidayat ini supaya saya belajar lebih santun, supaya saya lebih menjadi publik yang baik sesuai dengan harapan masyarakat DKI." (D1P2-7).

Dalam tuturan pertama, penutur menyatakan tuturannya dengan santun dan meyakinkan masyarakat dengan cara yang santun pula. Penutur juga menjanjikan jika ia terpilih nanti, ia akan menjadikan Jakarta lebih maju lagi dan mengatasi semua permasalahan yang terjadi di Jakarta. Dengan demikian, tuturan ini digolongkan sebagai bertutur basa-basi kesantunan positif. Penggunaan strategi basa-basi kesantunan positif juga digunakan pada tuturan kedua. Dari tuturan ketiga, berarti penutur merasa bersyukur atas apa yang telah ia berikan untuk Jakarta. Pernyataan ini disampaikan oleh paslon dua ketika menjelaskan visi-misi mereka. Penutur juga tidak membebankan siapa pun ketika ia menyampaikan tuturannya. Hal itu terlihat dari kalimat "saya juga bersyukur, sebagian orang Jakarta melihat hasil nyata”. Selanjutnya, tuturan 4 juga menggunakan sebagai bertutur basa-basi kesantunan positif. Hal ini terlihat dari kalimat "kami melayani. Ini adalah dasar pelayanan publik. Kami jadi pelayan yang miliki hasrat empati untuk layani masyarakat". Pernyataan ini diungkapkan oleh paslon dua ketika memberi tanggapan mengenai visi misi mereka. Dapat disimpulkan bahwa tuturan tersebut bertujuan menyenangkan hati lawan tutur. Lawan tutur akan merasa simpatik kepada penutur melalui tuturannya. Pada tuturan keempat, strategi basa-basi kesantunan positif ditunjukkan melalui frasa "mempertimbangkan kepentingan masyarakat nelayan dan reklamasi akan bisa menyerap 15 persen tenaga kerja". Dari tuturan tersebut, calon pemilih khususnya nelayan akan mempunyai harapan baru terhadap proyek reklamasi yang sedang dicanangkan paslon dua. Jadi, pihak yang dituju dalam tuturan merasa senang dan simpatik kepada penutur.

Penggunaan strategi basa-basi kesantunan positif juga terdapat pada tuturan kelima yang bertujuan membangun kesan positif terhadap dirinya. Hal ini terlihat pada kalimat "yang paling ideal ya kita harus berintegritas dengan rekam jejak yang baik, dan kita juga santun sebagai pejabat publik, makanya saya beruntung ada Mas Saiful Djarot Hidayat ini supaya saya belajar lebih santun, supaya saya lebih menjadi publik yang baik sesuai dengan harapan masyarakat." Kesan yang ditimbulkan dari pernyataan tersebut adalah penutur menjelaskan sosok pejabat ideal yang seharusnya ia miliki. Secara tersirat, penutur mengatakan bahwa dirinya akan belajar menjadi sosok tersebut. Dengan demikian, tuturan kelima cocok digolongkan ke dalam strategi bertutur basa-basi kesantunan positif.

4. Bertutur Samar-Samar

Berdasarkan identifikasi dan klasifikasi data, ditemukan 16 tuturan penggunaan strategi bertutur samar-samar dalam debat paslon pilkada DKI Jakarta 2017 salah satu contohnya berikut ini.

1) "Tapi yang paling penting adalah good will. Memberikan dan menjadi contoh bagi yang lainnya. Itu menjadi sangat penting barulah kita bisa mengajak birokrasi kita, mengajak masyarakat kita dan seluruh stakeholders di Jakarta ini untuk benar-benar menjaga integritasnya, memajukan Jakarta, menyejahterakan rakyat dan semuanya kembali untuk rakyat Jakarta." (D1P1-10)

2) "Bila tadi kita dengar, pasangan calon pertama memberikan ikannya. Pasangan kedua memberikan kailnya. Ikan dan kail baik diberikan. Tapi jika kolamnya masih ada, bagian kami menyiapkan, memastikan kolamnya masih tersedia. Di sini penting, apalah artinya dengan ikan dan kail bila kolamnya habis?" (D1P3-12)

3) "Kami bukan memerangi kemiskinan. Pendiri republik ini tidak pernah mengatakan memerangi kemiskinan. Mereka mengatakan memajukan kesejahteraan umum. Mereka mengatakan mencerdaskan kehidupan bangsa. Mereka tidak mengatakan memerangi kebodohan." (D1P3-13)

4) "Pertama aparatur pemerintah yang tidak kompeten butuhkan lebih dari sekedar good govermance, itu pendekatan era 90an. Sekarang eranya open govermance di mana pemerintah dan masyarakat membangun bekerja bersama-sama." (D2P3-3) 
Tuturan yang muncul dengan strategi bertutur samarsamar dapat dicontohkan tuturan pertama konteksnya adalah penutur menanggapi pertanyaan moderator mengenai program unggulan para paslon, dan tuturan ini disampaikan oleh paslon satu. Secara tidak langsung, makna yang tertangkap dari tuturan pertama adalah penutur menyindir pemerintah yang tidak dapat menjadi contoh bagi masyarakat namun tidak langsung menyebut pihak yang dituju. Dengan kata lain, sindiran ini diungkapkan secara samarsamar. Selanjutnya, tuturan kedua juga menggunakan strategi samar-samar dalam pengungkapannya. Hal itu terlihat dari semua kalimat dalam tuturan. Penutur menggunakan kata-kata kiasan sebagai perumpaan program-program dari paslon lain. Namun, dalam pernyataannya penutur lebih menekankan bahwa programnyalah yang lebih baik dari yang lain. Dengan demikian, strategi samar-samar cocok digolongkan untuk tuturan kedua. Kemudian, penjelasan contoh dari strategi bertutur samar-samar ditunjukkan oleh tuturan ketiga. Hal ini terlihat dari beberapa kalimat, yaitu "pendiri republik ini tidak pernah mengatakan memerangi kemiskinan. Mereka mengatakan memajukan kesejahteraan umum. Mereka mengatakan mencerdaskan kehidupan bangsa. Mereka tidak mengatakan memerangi kebodohan." Jika dikaitkan dengan konteksnya, ungkapan ini adalah bentuk sindiran secara tidak langsung dari paslon tiga terhadap paslon satu yang menyatakan bahwa mereka akan memerangi kemiskinan. Jadi, makna yang tertangkap dari tuturan ini adalah pemimpin seharusnya tidak mengatakan bahwa ia akan memerangi kemiskinan. Tuturan ini digolongkan kepada strategi bertutur samar-samar karena tidak diungkapkan secara langsung kepada pihak yang dituju. Tuturan keempat menggunakan frasa "itu pendekatan era 90-an" sebagai ungkapan strategi bertutur samar-samar. Lawan tutur tidak akan mengerti jika tidak dikaitkan dengan konteks tuturan tersebut. Ungkapan itu sebetulnya merupakan jawaban dari paslon tiga atas pertanyaan mengenai rendahnya kompetensi PNS di Jakarta. Secara tersirat, penutur menyatakan bahwa pemerintahan yang sedang menjabat sekarang masih menggunakan strategi-strategi lama untuk meningkatkan kompetensi PNS, akibatnya kompetensi PNS masih rendah dan tidak meningkat. Lalu, penutur juga memberikan saran kepada pemerintah mengenai hal tersebut.

\subsection{Penggunaan Prinsip Kesantunan Para Paslon Dalam Debat Pilkada DKI Jakarta}

Prinsip kesantunan dapat dibagi menjadi enam, yaitu: maksim kebijaksanaan, maksim kedermawanan, maksim penghargaan, maksim kerendahan hati, maksim kesepakatan, dan maksim kesimpatian. Terdapat dua cara untuk melihat prinsip kesantunan, yaitu maksim mematuhi dan maksim melanggar prinsip kesantunan.
Berikut data yang melanggar prinsip kesantunan, serta yang mematuhi prinsip kesantunan yang ditemukan dalam penelitian ini.

\subsubsection{Maksim Melanggar}

Prinsip kesantunan yang dilanggar para paslon dalam debat pilkada DKI Jakarta 2017 dirincikan ke dalam lima maksim sebagai berikut.

1. Maksim Kedermawanan

Pelanggaran prinsip kesantunan pada maksim kedermawanan ditemukan 8 tuturan dalam debat paslon pilkada DKI Jakarta 2017 salah satu contohnya berikut ini.

1) Tentu saya juga memaklumi selama 4 tahun lebih ini, banyak warga Jakarta hanya melihat penampilan saya. Terlalu menggebu-gebu, terlalu semangat. Akibatnya visi-misi yang sudah kami capai, program yang sudah terukur, hilang. Sebagian melihat saya terlalu temperamental (D1P2-1)

2) Izinkan kami untuk tuntaskan yang sudah kami awali. Mohon doa restu dan jangan takut untuk memilih sesuai hati (D2P2-1

3) Kami butuhkan 5 tahun lagi, kita akan tunjukkan bahwa anak-anak DKI bisa unggul sampai perguruan tinggi dengan beasiswa". (D2P2-4)

4) Yah ini memang mungkin pasangan calon 1 lihatnya hanya lokasi tertentu. Kami tuh tidak pernah menggusur daerah yang tidak tinggal di dalam aliran sungai sebetulnya. (D4P2-1)

5) Jadi sekali lagi seolah-olah kami mengusir orang Jakarta. Yang tidak mendapat rusun, itu adalah penyewa yang datang dari luar kota sebetulnya. Tapi kalau dia ber-KTP DKI pasti dapat rusun (D4P2-3)

Tuturan pertama, penutur terlihat melanggar maksim kedermawanan. Dalam hal ini, penutur menampakkan sikap mengeluh bahwa dirinya selama ini dirugikan. Hal tersebut terlihat dari pernyataan "banyak warga Jakarta hanya melihat penampilan saya" dan "akibatnya visi-misi yang sudah kami capai, program yang sudah terukur, hilang". Keluhan yang diungkapkan si penutur menandai bahwa penutur tidak menerima atas kerugian yang dialaminya, atau tidak ingin memaksimalkan kerugian pada dirinya. Selanjutnya pada tuturan kedua, penutur terlihat melanggar maksim kedermawanan karena memaksimalkan keuntungan bagi dirinya. Hal itu terlihat pada pernyataan "izinkan kami untuk tuntaskan yang sudah kami awali”. Dalam hal ini, penutur bermaksud untuk diberikan kesempatan agar dirinya bisa menuntaskan hal yang sudah diawalinya, yang tentunya secara tidak langsung si penutur mendapatkan keuntungan dari tuturan tersebut. Begitu juga halnya pada tuturan ketiga, penutur terlihat melanggar maksim kedermawanan karena memaksimalkan keuntungan bagi dirinya. Hal itu terlihat pada pernyataan "kami butuhkan 5 tahun lagi". Dalam 
hal ini , penutur bermaksud untuk meminta waktu 5 tahun lagi, yang tentunya secara tidak langsung si penutur ingin mendapatkan keuntungan dari tuturan tersebut.

Tuturan keempat penutur terlihat melanggar maksim kedermawanan. Dalam hal ini, penutur menampakkan sikap mengeluh. Hal tersebut terlihat dari pernyataan "yah ini memang mungkin pasangan calon 1 lihatnya hanya lokasi tertentu" dan "kami tuh tidak pernah menggusur daerah yang tidak tinggal di dalam aliran sungai sebetulnya". Keluhan yang diungkapkan si penutur menandai bahwa penutur tidak menerima atas kerugian yang dialaminya, atau tidak ingin memaksimalkan kerugian pada dirinya atas dampak dari pernyataan dari paslon lain. Begitupun tuturan kelima, tuturan ini melanggar maksim kedermawanan. Dalam hal ini, penutur menampakkan sikap mengeluh. Hal tersebut terlihat dari pernyataan "Jadi sekali lagi seolaholah kami mengusir orang Jakarta". Keluhan yang diungkapkan si penutur menandai bahwa penutur tidak menerima atas kerugian yang dialaminya, atau tidak ingin memaksimalkan kerugian pada dirinya atas dampak dari paradigma yang berkembang selama ini tentang dirinya.

2. Maksim Pujian

Pelanggaran prinsip kesantunan pada maksim pujian ditemukan 14 tuturan dalam debat paslon pilkada DKI Jakarta 2017 salah satu contohnya berikut ini.

1) Pertama aparatur pemerintah yang tidak kompeten butuhkan lebih dari sekedar good governance, itu pendekatan era 90an. Sekarang eranya open governance di mana pemerintah dan masyarakat membangun bekerja bersama-sama (D2P3-3)

2) Kedua, tidak hanya dengan berikan iming-iming tunjangan kinerja. Itu baik, karena berikanstick. Tapi budaya, pemimpin harus mendukung bukan memukul, harus memotivasi (D2P3-4)

3) Birokrasi bertanggung jawab untuk memastikan seluruh warganya. Per orang di Jakarta miliki aset Rp100 juta. Ini dimanfaatkan birokrasi untuk keadilan. Sudahkah itu terjadi? Belum (D2P3-5)

4) Dari presiden Soeharto, kita bisa melihat seorang figur yang stabil, tidak emosional, dan bisa memetakan masalah," (D3P3-2)

5) Jadi saya hanya ingin bertanya Pak, itu kan tentu dokumenter yang menggambarkan derita dan nestapa dari warga Jakarta. Rakyat kecil yang hidupnya sudah sangat sulit dan akhirnya tergusur ke tempat lain. Bapak punya alasan tentunya mengapa menggusur, tetapi bagaimana perasaan bapak sebagai pemimpin sekaligus pengambil kebijakan tersebut melihat warga yang hidupnya semakin sulit begitu semakin sulit dan akhirnya kehilangan segalanya?. (D4P3-1)

Tuturan pertama merupakan tuturan yang melanggar maksim pujian, yaitu maksim yang bermaksud untuk mengecam muka lawan tuturnya. Hal itu terlihat pada ungkapan "sekarang eranya open governance di mana pemerintah dan masyarakat membangun bekerja bersama-sama" bermaksud untuk mengkritik paslon lain yang dianggap kurang membangun kerja sama antara pemerintah dan masyarakat. Selain itu, penutur juga mengecam muka lawan tutur dengan mengkritik paham dari paslon lain yang dianggap sudah ketinggalan jaman. Hal tersebut ditandai dengan pernyataan "aparatur pemerintah yang tidak kompeten butuhkan lebih dari sekedar good governance, itu pendekatan era 90an".

Selanjutnya, tuturan kedua juga juga merupakan tuturan yang melanggar maksim pujian. Penggunaan kalimat "budaya, pemimpin harus mendukung bukan memukul, harus memotivasi" bermaksud untuk menyindir pemimpin yang dianggap tidak memotivasi atau mendukung dengan cara yang baik atau menyakiti orang yang dipimpinnya. Tuturan ketiga merupakan tuturan yang melanggar maksim pujian, yaitu maksim yang bermaksud untuk mengecam muka lawan tuturnya. Hal itu terlihat pada ungkapan "birokrasi untuk keadilan. Sudahkah itu terjadi? Belum" yang mengecam muka pihak yang dimaksud dengan cara mengkritik secara langsung sistem birokrasi yang dianggap belum dimanfaatkan untuk menegakkan keadilan

Lalu, tuturan keempat juga merupakan melanggar maksim pujian. Penggunaan kalimat "kita bisa melihat seorang figur yang stabil, tidak emosional, dan bisa memetakan masalah" secara tidak langsung terkesan untuk menyindir pemimpin yang dianggap tidak bisa mengontrol emosi serta tidak bisa memetakan atau menempatkan masalah dengan tepat. Tuturan kelima merupakan tuturan yang melanggar maksim pujian, yaitu tuturan yang bermaksud untuk mengecam muka lawan tuturnya. Penggunaan kalimat "itu kan tentu documenter yang menggambarkan derita dan nestapa dari warga Jakarta" serta "Bapak punya alasan tentunya mengapa menggusur, tetapi bagaimana perasaan bapak sebagai pemimpin sekaligus pengambil kebijakan tersebut melihat warga yang hidupnya semakin sulit begitu semakin sulit dan akhirnya kehilangan segalanya" yang secara tidak langsung terkesan menyindir lawan tutur yang dianggap tidak memperdulikan penderitaan rakyat yang kehilangan segalanya karena penggusuran.

3. Maksim Kesepakatan

Pelanggaran prinsip kesantunan pada maksim kesepakatan ditemukan 12 tuturan dalam debat paslon pilkada DKI Jakarta 2017 salah satu contohnya berikut ini.

1) Selain yang sudah baik, potret Jakarta hari ini, ketimpangan meningkat, daya beli sebagian masyarakat menurun,disamping itu kualitas hidup masyarakat menurun akibat banjir, macet, sampah yang tidak bisa terselesaikan dengan baik. (D1P1-1)

2) Manusia Jakarta yang kita bangun adalah otaknya harus penuh, perutnya juga penuh, dan dompetnya juga penuh. Masyarakat Jakarta kalau otaknya penuh, berarti dia cerdas, dia berkarakter, dan dia 
mempunyai daya beli yang tinggi. Ini hanya bisa dilalui kalau birokrasinya betul-betul bersih dan melayani, serta profesional. (D1P2-4)

3) Integritas adalah soal keberpihakan pada nilai. Karena itu, sebagai contoh, ketika kita dihadapkan dengan ketimpangan yang luar biasa, kita menyaksikan ketimpangan yang sedang dibuat, yaitu reklamasi. Posisi kita tegas. Kita menolak reklamasi. Karena ini adalah conoh bagaimana kita akan menyaksikan sebuah tempat yang nanti akan menjadi enclave. (D1P3-11)

4) Karena kami melaksanakan enam program. Jaminan kesehatan ini adalah tanggungan semesta (D1P2-11)

5) Sekarang bagaimana logikanya, kalau sampe moratorium mobil mewah tidak boleh masuk? Justru kalau seperti ini yang terjadi adalah mobilmobil murah yang ramah lingkungan yang akan masuk dan Jakarta akan macet. Yaa Aakah solusi seperti ini memang bisa memecahkan persoalan kemacetan di Jakarta? (D4P2-4)

Tuturan pertama merupakan tuturan yang melanggar maksim kesepakatan. Hal tersebut ditandai dengan pernyataan "potret Jakarta hari ini, ketimpangan meningkat, daya beli sebagian masyarakat menurun,disamping itu kualitas hidup masyarakat menurun akibat banjir, macet, sampah yang tidak bisa terselesaikan dengan baik". Dalam hal ini dapat disimpulkan bahwa penutur menganggap bahwa masih banyak permasalahan di Jakarta yang belum terselesaikan dengan baik. Artinya penutur terlalu berlebihan dalam mengungkapkan pendapatnya serta menyimpulkan sesuatu secara sepihak tanpa memikirkan apakah pendapat tersebut disetujui atau tidak oleh pihakpihak tertentu.. Tuturan kedua merupakan tuturan yang melanggar maksim kesepakatan karena penutur secara sepihak menyimpulkan sesuatu. Hal itu terlihat pada pernyataan "Ini hanya bisa dilalui kalau birokrasinya betul-betul bersih dan melayani, serta professional". Selanjutnya, tuturan ketiga merupakan tuturan yang melanggar maksim kesepakatan. Hal tersebut ditandai dengan pernyataan "Kita menolak reklamasi. Karena ini adalah contoh bagaimana kita akan menyaksikan sebuah tempat yang nanti akan menjadi enclave". Dalam hal ini dapat disimpulkan bahwa penutur menganggap bahwa reklamasi nantinya akan menjadi polemik seperti terjadinya enclave dan menyatakan secara tegas akan menolak reklamasi. Artinya penutur terlalu berlebihan dalam mengungkapkan pendapatnya serta menyimpulkan sesuatu secara sepihak tanpa memikirkan apakah pendapat tersebut disetujui atau tidak oleh pihakpihak tertentu.

Berikutnya, tuturan keempat merupakan tuturan yang melanggar maksim kesepakatan. Hal tersebut ditandai dengan pernyataan "Jaminan kesehatan ini adalah tanggungan semesta". Dalam hal ini dapat disimpulkan bahwa penutur menganggap bahwa sebenarnya jaminan kesehatan itu merupakan tanggung jawab semuanya. Artinya penutur telah menyimpulkan suatu permasalahan secara sepihak tanpa memikirkan apakah pendapat tersebut disetujui atau tidak oleh pihakpihak tertentu. Tuturan kelima juga merupakan tuturan yang melanggar maksim kesepakatan. Hal tersebut ditandai dengan pernyataan "Justru kalau seperti ini yang terjadi adalah mobil-mobil murah yang ramah lingkungan yang akan masuk dan Jakarta akan macet". Dalam hal ini, penutur ingin menyampaikan bahwa jika moratorium mobil mewah tidak boleh masuk mobilmobil murah yang akan banyak masuk dan hal inilah yang akan menyebabkan kemacetan. Artinya penutur terlalu berlebihan dalam mengungkapkan pendapatnya serta menyimpulkan sesuatu secara sepihak tanpa memikirkan apakah pendapat tersebut disetujui atau tidak oleh pihak-pihak tertentu.

4. Maksim Kerendahan Hati

Pelanggaran prinsip kesantunan pada maksim kerendahan hati ditemukan 25 tuturan dalam debat paslon pilkada DKI Jakarta 2017 salah satu contohnya berikut ini.

1) Supaya kalau kami dilanjutkan lagi bukan hanya visimisi program tercapai tapi Ahok-nya sudah mencari iCore7, i7, bukan Pentium lagi kalau komputer. Sehingga kami akan lebih baik, kesalahpahaman ini akan bisa dihindari. (D1P2-3)

2) Kami hadir di Jakarta membawa pengalaman pengetahuan dan akumulasi jaringan. (D1P3-1)

3) Ya ada orang mengatakan integritas atau karakter baru teruji ketika anda diberikan kekuasaan. Kami bersyukur kami berdua ini adalah orang yang sudah pernah berkuasa jadi bupati, walikota, DPRD, DPR RI, saya wagub, gubernur, sehingga karakter kami teruji dari apa yang telah kami lakukan. (D1P2-6)

4) Iya memang kita ketahui, gini ratio di DKI lebih tinggi di nasional. Tapi kita jangan lupa tahun 2013 ketika kami masuk ke DKI, perbedaan ratio gini ratio DKI dengan nasional itu jauh sekali, 0.43 dan 0.41 . Nah sekarang kita sudah 0.41 dan 0.4. (D1P2-8)

5) Kami bukan bicara soal keadilan sosial saja, kami adalah orang yang telah melawan ketidakadilan. Ketika oknum-oknum PNS mengingkari sumpah jabatan, menekan, mempersulit, kami lawan semua, kami singkirkan. (D2P3-1)

Tuturan pertama terlihat penutur melanggar maksim kerendahan hati. Artinya penutur terlalu berlebihan memuji dirinya sendiri. Hal itu terlihat dari pernyataan"Ahok-nya sudah mencari iCore7, i7, bukan Pentium lagi kalau komputer. Sehingga kami akan lebih baik, kesalah pahaman ini akan bisa dihindari". Begitu juga halnya dengan tuturan kedua. Pada tuturan kedua penutur melanggar maksim kerendahan hati. Hal itu terlihat dari pernyataan kalimat "kami hadir di Jakarta membawa pengalaman pengetahuan dan akumulasi jaringan". Dari tuturan tersebut terlihat bahwa penutur terlalu berlebihan dalam memuji dirinya sendiri. Tuturan ketiga terlihat penutur melanggar maksim kerendahan 
hati. Artinya penutur terlalu berlebihan memuji dirinya sendiri. Hal itu terlihat dari pernyataan "karakter kami teruji dari apa yang telah kami lakukan" pada kalimat tersebut, penutur bermaksud memuji diri sendiri dengan mengatakan dirinya sudah teruji dan terkesan terlalu berlebihan dalam menyanjung dirinya sendiri. Tuturan keempat penutur melanggar maksim kerendahan hati yang terlihat dari pernyataan "Tapi kita jangan lupa tahun 2013 ketika kami masuk ke DKI, perbedaan ratio gini ratio DKI dengan nasional itu jauh sekali, 0.43 dan 0.41. Nah sekarang kita sudah 0.41 dan 0.4". Dari ungkapan tersebut terkesan bahwa si penutur menyombongkan tentang keberhasilannya dalam menurunkan perbedaan gini ratio mengenai ketimpangan ekonomi di Jakarta. Dengan demikian, tuturan melanggar maksim kerendahan hati karena si penutur terlalu memaksimalkan pujian pada dirinya atau pihaknya.

Lalu, tuturan kelima merupakan tuturan yang melanggar maksim kerendahan hati yang terlihat dari pernyataan "kami bukan bicara soal keadilan sosial saja, kami adalah orang yang telah melawan ketidakadilan". Dari ungkapan tersebut terkesan bahwa si penutur menyombongkan bahwa dirinya dan rekannya adalah orang yang selama ini melawan ketidakadilan. Dengan demikian, tuturan kelima melanggar maksim kerendahan hati karena si penutur terlalu memaksimalkan pujian pada dirinya atau pihaknya.

5. Maksim Kesimpatian

Pelanggaran prinsip kesantunan pada maksim kesimpatian ditemukan 11 tuturan dalam debat paslon pilkada DKI Jakarta 2017 salah satu contohnya berikut ini.

1) Tentunya meningkatkan kualitas lingkungan hidup dengan cara solusi yang efektif untuk mengatasi problem yang akut seperti banjir, sampah, dan polusi. Dan terakhir, dan tidak kalah penting adalah meyakinkan hadirnya rasa aman dan adil untuk seluruh warga Jakarta. (D1P1-4)

2) Integritas bukan hanya soal jujur. Firaun pencuri pun bisa dengan jujur menceritakannya. Integritas adalah jujur secara pribadi berpihak kepada kepentingan publik, menjalankan nilai-nilai dengan benar dan tidak kalah penting adalah selalu mengikuti tata kelola yang baik. (D1P3-10)

3) Tapi yang paling penting adalah good will. Memberikan dan menjadi contoh bagi yang lainnya. Itu menjadi sangat penting barulah kita bisa mengajak birokrasi kita, mengajak masyarakat kita dan seluruh stakeholders di Jakarta ini untuk benar-benar menjaga integritasnya, memajukan Jakarta, menyejahterakan rakyat dan semuanya kembali untuk rakyat Jakarta. (D1P1-10)

4) Saya melihat ada ketidakberpihakan, pada sistem sekarang. Dimana yang kaya makin kaya, yang miskin makin miskin. Yang usaha besar makin besar, yang usaha kecil makin terpuruk (D1P3-16).
5) Yang pertama begini, kalau ada pemimpin yang ingin membantu rakyatnya berdasar konstitusi membantu rakyat miskin, dianggap membodohi. Saya pikir itu tidak punya hati. (D1P1-15)

Tuturan pertama terdapat pelanggaran maksim kesimpatian yang disampaikan penutur terhadap pihak yang dimaksud. Ketidak simpatian tersebut. Terlihat pada kalimat "mengatasi problem yang akut seperti banjir, sampah, dan polusi. Dan terakhir, dan tidak kalah penting adalah meyakinkan hadirnya rasa aman dan adil untuk seluruh warga Jakarta". Artinya penutur menyatakan ketidaksimpatian dengan pihak yang dimaksud, karena ungkapan tersebut secara tidak langsung menyindir pemimpin yang selama ini belum bisa menemukan cara yang efektif dalam menyelesaikan pihak. Apalagi sampai menyebut "problem yang akut", yang dapat diartikan sebagai permasalahan yang sudah berkepanjangan yang tidak dapat diselesaikan. Tuturan kedua terdapat pelanggaran maksim kesimpatian. Hal tersebut terlihat dari pernyataan "Integritas bukan hanya soal jujur. Firaun pencuri pun bisa dengan jujur menceritakannya. Integritas adalah jujur secara pribadi berpihak kepada kepentingan publik, menjalankan nilainilai". Dalam hal ini, penutur melihatkan antipatinya terhadap pihak yang hanya meletakkan integritasnya kepada kejujuran namun tidak berpihak kepada kepentingan publik dan tidak menegakkan nilai-nilai.

Tuturan ketiga terdapat pelanggaran maksim kesimpatian. Hal tersebut terlihat dari pernyataan "yang paling penting adalah good will. Memberikan dan menjadi contoh bagi yang lainnya barulah kita bisa mengajak birokrasi kita, mengajak masyarakat kita dan seluruh stakeholders di Jakarta ini untuk benar-benar menjaga integritasnya". Dalam hal ini, penutur melihatkan antipatinya terhadap pemimpin yang tidak bisa menjadi contoh bagi rakyat atau orang yang dipimpinnya. Tuturan keempat terdapat pelanggaran maksim kesimpatian yang disampaikan penutur dengan pernyataan "Saya melihat ada ketidakberpihakan, pada sistem sekarang. Dimana yang kaya makin kaya, yang miskin makin miskin. Yang usaha besar makin besar, yang usaha kecil makin terpuruk". Dalam hal ini, penutur melihatkan antipatinya terhadap sistem yang hanya menguntungkan bagi pihak-pihak yang berkuasa atau kaya, dan menjadikan rakyat yang miskin semakin terpuruk.

Tuturan keempat terdapat pelanggaran maksim kesimpatian. Hal tersebut terlihat dari pernyataan saya melihat ada ketidakberpihakan, pada sistem sekarang. Dimana yang kaya makin kaya, yang miskin makin miskin. Tuturan tersebut bertujuan untuk mengungkapkan rasa ketidaksimpatiannya kepada pemerintah dalam memberdayakan masyarakat. Tuturan kelima merupakan tuturan yang melanggar maksim kesimpatian dengan tuturan "kalau ada pemimpin yang ingin membantu rakyatnya berdasar konstitusi membantu rakyat miskin, dianggap membodohi. Saya pikir itu tidak punya hati". Ungkapan "tidak punya hati" 
memperlihatkan antipati penutur terhadap orang yang menyatakan bahwa pemimpin yang membantu rakyat miskin karena dianggap membodohi.

\subsubsection{Maksim Mematuhi}

Prinsip kesantunan yang dipatuhi para paslon dalam debat pilkada DKI Jakarta 2017 dirincikan ke dalam enam maksim sebagai berikut.

1. Maksim Kebijaksanaan

Tuturan yang mematuhi maksim kebijaksanaan ditemukan 8 tuturan dalam debat paslon pilkada DKI Jakarta 2017 salah satu contohnya berikut ini.

1) Jakarta bukan tempat uji coba. Kami menempatkan Jakarta sebagai tempat untuk kita mengabdi, mengajak maju bersama dan Insya Allah tempat berpahala bagi semua. (D1P3-2)

2) Kita ingin para orang tua bisa mengantarkan anaknya ke sekolah, bisa mengantarkan anaknya ke madrasah, dengan perasaan tenang, dengan perasaan yakin, dengan penuh cinta kasih. (D1P3-4)

3) Demikian juga mereka-mereka yang kebetulan dia sakit di rumah dan butuh pertolongan, butuh bantuan, pemerintah akan hadir untuk membantu mereka. Inilah gunanya pemerintah hadir di tengah-tengah masyarakat. (D1P2-5)

4) Kami ingin juga meningkatkan pendidikan dan kesejahteraan guru. (D1P1-6)

5) Jakarta punyai 135.222 pegawai PNS dan Non-PNS. Kami akan pastikan mereka bekerja maksimal layani warga dengan hati. (D2P2-5)

Pada tuturan pertama penutur terlihat mematuhi maksim kebijaksanaan karena tuturannya memaksimalkan keuntungan bagi orang lain. Hal tersebut terlihat dari pernyataan "kami menempatkan Jakarta sebagai tempat untuk kita mengabdi, mengajak maju bersama dan Insya Allah tempat berpahala bagi sетиа". Dalam hal ini penutur terlihat memikirkan keuntungan untuk sesama dan mengenyampingkan kepentingan pribadinya. Begitu juga halnya tuturan kedua terlihat penutur mematuhi maksim kebijaksanaan karena penutur menyatakan sesuatu demi kepentingan atau keuntungan bagi orang lain. Hal tersebut terlihat dari pernyataan "kita ingin para orang tua bisa mengantarkan anaknya ke sekolah, bisa mengantarkan anaknya ke madrasah, dengan perasaan tenang, dengan perasaan yakin, dengan penuh cinta kasih". Pada tuturan ketiga, penutur terlihat mematuhi maksim kebijaksanaan karena tuturannya memaksimalkan keuntungan bagi orang lain. Hal tersebut terlihat dari pernyataan "inilah gunanya pemerintah hadir di tengah-tengah masyarakat". Dalam hal ini, penutur ingin mengungkapkan bahwa sebagai pemerintah dia harus bertanggungjawab dalam membantu masyarakat yang membutuhkan atau sedang mengalami kesulitan.

Selanjutnya pada tuturan keempat, penutur mematuhi maksim kebijaksanaan karena tuturannya juga memaksimalkan keuntungan bagi orang lain. Hal tersebut terlihat dari pernyataan "kami ingin juga meningkatkan pendidikan dan kesejahteraan guru”. Dalam hal ini penutur menyatakan keinginannya untuk meningkatkan pendidikan dan kesejahteraan guru yang tentunya hal ini akan menguntung bagi orang lain dan juga terutama seorang guru. Pada tuturan kelima, penutur mematuhi maksim kebijaksanaan karena tuturannya juga memaksimalkan keuntungan bagi orang lain. Hal tersebut terlihat dari pernyataan "kami akan pastikan mereka bekerja maksimal layani warga dengan hati". Dalam hal ini penutur menyatakan keinginannya untuk meningkatkan kinerja PNS dalam melayani masyarakat, yang tentunya hal ini memaksimalkan keuntungan bagi orang banyak.

2. Maksim Kedermawanan

Tuturan yang mematuhi maksim kedermawanan ditemukan 2 tuturan dalam debat paslon pilkada DKI Jakarta 2017 salah satu contohnya berikut ini.

1) Saya akan berdiri yang terdepan bersama seluruh warga Jakarta untuk mengubah warga ibukota menjadi semakin modern, unggul, tetapi tetap menjadi kota yang manusiawi dan selalu berjati diri, berkarakter pada Jakarta dan Indonesia yang kita cintai. (D1P1-5)

2) Ketika kita bicara pelayanan publik, pada 2013, kami keluarkan badan layanan terpadu satu pintu Kenapa badan pelayanan, bukan perizinan? Perizinan itu warga datang kepada kami, memberi izin atau tidak. Kalau pelayanan, wargalah atasan kami. Kami melayani. Ini adalah dasar pelayanan publik. Kami jadi pelayan yang miliki hasrat empati untuk layani masyarakat. (D2P2-22)

Pada tuturan pertama, penutur terlihat mematuhi maksim kedermawanan karena tuturannya memaksimalkan kerugian bagi dirinya sendiri. Hal tersebut terlihat dari pernyataan "saya akan berdiri yang terdepan". Dalam hal ini penutur terlihat memikirkan keuntungan untuk sesama dan mengenyampingkan kepentingan pribadinya. Pada tuturan kedua, penutur terlihat mematuhi maksim kedermawanan karena tuturannya memaksimalkan kerugian bagi dirinya sendiri. Hal tersebut terlihat dari pernyataan "kalau pelayanan, wargalah atasan kami. Kami melayani.Ini adalah dasar pelayanan publik. Kami jadi pelayan yang miliki hasrat empati untuk layani masyarakat". Ungkapan "kami jadi pelayan" adalah bentuk penutur memaksimalkan kerugian bagi dirinya.

3. Maksim Pujian

Tuturan yang mematuhi maksim pujian ditemukan 1 tuturan dalam debat paslon pilkada DKI Jakarta 2017 salah satu contohnya berikut ini.

Saya juga bersyukur, sebagian orang Jakarta melihat hasil nyata. Sungai lebih bersih. Semua kelihatan. Pelayanan lebih baik. Terutama, misalnya saya beri contoh, saya bersyukur punya Mas Djarot, yang melihat apa yang telah saya kerjakan dan saya juga belajar terus dari Mas Djarot. Namanya juga Djarot Saiful Hidayat. Supaya saya agak-agak mirip dengan beliau. (D1P2-2) 
Tuturan pertama penutur terlihat mematuhi maksim pujian dengan cara memaksimalkan pujian kepada pihak yang dimaksud. Hal tersebut terlihat dari pernyataan "saya juga bersyukur, sebagian orang Jakarta melihat hasil nyata", "saya bersyukur punya Mas Djarot" serta "saya juga belajar terus dari Mas Djarot" bermaksud memuji masyarakat Jakarta yang melihat hasil nyata, serta memuji Djarot yang bisa dijadikan teladan.

4. Maksim Kerendahan Hati

Tuturan yang mematuhi maksim kerendahan hati dalam debat paslon pilkada DKI Jakarta 2017 salah satu contohnya berikut ini.

Jadi kalau ada tim sukses saya yang mengatakan, nggak papa nggak santun, yang penting jujur. Salah, saya bilang. Atau ya buat apa, jujur atau kelihatan santun, tapi nggak jujur. Salah. Yang paling ideal ya kita harus berintegritas dengan rekam jejak yang baik, dan kita juga santun sebagai pejabat publik, makanya saya beruntung ada Mas Saiful Djarot Hidayat ini supaya saya belajar lebih santun, supaya saya lebih menjadi publik yang baik sesuai dengan harapan masyarakat DKI. (D1P2-7)

Tuturan pertama terdapat pematuhan maksim kerendahan hati dengan memaksimalkan pujian terhadap orang lain. Hal tersebut terlihat dari pernyataan "saya beruntung ada Mas Saiful Djarot Hidayat ini supaya saya belajar lebih santun, supaya saya lebih menjadi publik yang baik sesuai dengan harapan masyarakat DKI'. Dalam hal ini penutur memuji Djarot yang dianggap santun dalam berbicara.

5. Maksim Kesepakatan

Tuturan yang mematuhi maksim kesepakatan ditemukan 3 tuturan dalam debat paslon pilkada DKI Jakarta 2017 salah satu contohnya berikut ini.

1) Semoga ini semua semakin menyejahterakan masyarakat Jakarta dan kita semua hidup lebih baik lagi.(D1P1-8)

2) Insya Allah, jika saya dan Mpok Sylvi terpilih menjadi Gubernur dan Wakil Gubernur Jakarta, kami berdua akan menjaga integritas kami. (D1P1-9)

3) Kita memiliki bantuan atau skema bantuan dana bergulir. Modal usaha tanpa bunga yang tepat sasaran dengan pendampingan. Dan diharapkan dapat mengembangkan UMKM, sekaligus bisa mengurangi pengangguran juga. Ini kita harapkan dapat mengurangi pengangguran cukup signifikan selama lima tahun ke depan. (D1P1-13)

Tuturan pertama terdapat pematuhan maksim kesepakatan dengan menuturkan sesuatu yang tidak terlalu berlebihan sehingga apa yang disampaikan dapat memberikan persetujuan pihak tertentu. Hal tersebut terlihat dari pernyataan "semoga ini semua semakin menyejahterakan masyarakat Jakarta". Ungkapan "semoga" pada tuturan tersebut melihatkan bahwa penutur tidak berusaha menyimpulkan secara sepihak apa yang dituturkannya. Tuturan kedua terdapat pematuhan maksim kesepakatan dengan menuturkan sesuatu yang tidak terlalu berlebihan sehingga apa yang disampaikan dapat memberikan persetujuan pihak tertentu. Hal tersebut terlihat dari pernyataan "insya Allah, jika saya dan Mpok Sylvi terpilih menjadi Gubernur dan Wakil Gubernur Jakarta, kami berdua akan menjaga integritas kami". Ungkapan "Insya Allah" pada tuturan tersebut mengisyaratkan bahwa penutur tidak mau menyimpulkan atau memastikan sesuatu secara sepihak mengenai apa yang dituturkannya. Tuturan ketiga terdapat pematuhan maksim kesepakatan dengan menuturkan sesuatu yang tidak terlalu berlebihan sehingga apa yang disampaikan dapat memberikan persetujuan pihak tertentu. Hal tersebut terlihat dari pernyataan "ini kita harapkan dapat mengurangi pengangguran cukup signifikan selama lima tahun ke depan". Ungkapan "kita harapkan" pada tuturan tersebut melihatkan bahwa penutur tidak berusaha menyimpulkan secara sepihak apa yang dituturkannya.

6. Maksim Kesimpatian

Tuturan yang mematuhi maksim kesimpatian ditemukan 1 tuturan dalam debat paslon pilkada DKI Jakarta 2017 salah satu contohnya berikut ini.

Kita tahu bahwa masyarakat masalah ketimpangan gini ratio masih cukup tinggi. Dan ini harus kita selesaikan dengan cara menarik simpati dari mereka yang sudah luar biasa hidupnya untuk membantu saudara-saudaranya yang lemah. (D1P1-14)

Tuturan pertama terdapat pematuhan maksim kesimpatian dengan memaksimalkan rasa simpati bagi orang lain. Hal tersebut ditandai dengan pernyataan "dan ini harus kita selesaikan dengan cara menarik simpati dari mereka yang sudah luar biasa hidupnya untuk membantu saudara-saudaranya yang lemah". Dalam hal ini penutur mengajak untuk memberikan rasa peduli pada rakyat yang tidak mampu dan saling meringankan.

\section{KESIMPULAN}

Penggunaan kajian sosiopragmatik seperti jenis tindak tutur para paslon dalam debat Pilkada DKI Jakarta 2017 dominan pada tindak tutur ekspresif dan representatif. Gaya bahasa para paslon dalam debat Pilkada DKI Jakarta 2017 dominan memilih majas ironi dan sinisme. Ketiga, strategi bertutur yang digunakan oleh para paslon dalam debat Pilkada DKI Jakarta dominan pada strategi bertutur terus terang dan kesantunan negatif. Prinsip kesantunan kajian sosiopragmatik yang dilanggar lebih dominan daripada yang dipatuhi oleh para paslon. Tingkat kesantunan para paslon dalam debat Pilkada DKI Jakarta 2017 dapat digolongkan dalam tiga kategori, yaitu bertutur tidak santun, bertutur 'kurang santun, dan bertutur 'agak santun. Dilihat dari persentase yang digunakan, meskipun masih ada yang bertutur kurang santun dan santun, namun secara dominan tingkat kesantunan berbahasa para paslon dalam debat Pilkada DKI berada pada posisi 'agak kurang santun'. 


\section{SARAN}

Para paslon yang akan berkompetisi dalam Pilkada, hendaknya mempergunakan bahasa yang santun sesuai dengan kajian sosiopragmatik, memperhatikan segi tuturan, gaya bahasa dan strategi bertutur dalam setiap acara, apalagi di ranah public speacking, baik di media massa maupun di media sosial. Para politikus dan/atau pejabat pemerintahan supaya membudayakan dan mewajibkan penggunaan bahasa yang santun, baik di lingkungan formal maupun di lingkungan nonformal supaya dapat menjadi teladan bagi bawahan dan masyarakat secara umumnya. Masyarakat, selain menggunakan bahasa yang santun dalam berkomunikasi dalam kajian sosioragmatik, namun juga mampu menyaring ujaran yang disampaikan oleh para politikus sehingga tidak terpengaruh dan terprofokatori dengan pernyataan-pernyataan yang dilontarkannya. Peneliti selanjutnya, hasil penelitian ini dapat dijadikan sebagai studi awal atau relevan dan sebagai pembanding untuk penelitian selanjutnya.

\section{DAFTAR PUSTAKA}

Afrizal.2014. Metode Penelitian Kualitatif. Jakarta: PT Raja Grafindo Persada.

Agustina. 2017. Pragmatik dalam Pengajaran Bahasa Indonesia. Padang: IKIP Padang.

Asidi, D. 2015. Komunikasi Lisan. Yogyakarta: PD. Lukman

Chaer, A dan Leonie A. 2012 .Sosiolinguistik: Perkenalan Awal. Jakarta: PT Rineka Cipta.

Dicket, C. 2011. Formal forms er verbal strategis? Politeness theory and Japaness business etiquette training, Journal pragmatic, Vol. 10, No 10, pp. 5-6

Grebelsky, T. 2014. The role of verbal and nonverbal behaviuor Televised political debates, Journal published online, Vol. 10, No 15, pp. 16-17.

Halid, E. 2011. Santun Berbahasa. Padang: Sukabina Press.

Joseph, C. 2011. The use of demonstrative and context activation in catalan parliamentary debate, Journal pragmatic, Vol. 10, No 16, pp. 27-28.
Keraf, Gorys. 2014. Diksi dan Gaya Bahasa. Jakarta: Gramedia.

Markhamah, dan Atiqa S. 2013. Analsisis Kesalahan dan Kesantunan Berbahasa. Surakarta: Muhammadiyah University Press.

Papacharissi, Z. 2014. Democracy online: civility politeness and the democratic potential political discussions groups, Journal of published, Vol. 23, No 2, pp, 4-6.

Rakzadian, M. 2012. Politeeness principle in 2008 presidential debates between Mc Cain and Obama, Journal of social sciences, Vol. 3, No 3, pp, 2-6.

Smith, S. 2011. Honorifics Politeness an power in Japaness political, Journal pragmatic, Vol. 10, No, 6, pp, 12-16.

Tarigan, H. G. 2011. Berbicara Sebagai Suatu Keterampilan Berbahasa. Bandung: Angkasa.

Wacker, M. 2011. That is your evidence? Classifying stance in online political debate, Journal pragmatic, Vol. 10, No 13, pp, 12-16.

Wareing, S. dan Linda T. 2013.Bahasa Masyarakat dan Kekuasaan. Yogyakarta: Pustaka Pelajar.

Yethin, N. 2015. A pragmatics analysis of derogration in the discourse of political criticism in the Turkish grand national assembly, Journal faculty, Vol. 2, No 10, pp, 35-36.

Zamzani, dkk. 2012. Pengembangan Alat Ukur Kesantunan Bahasa Indonesia dalam Interaksi Sosial Bersemuka dan Non Bersemuka. Laporan Penelitian Hibah Bersaing (Tahun Kedua). Yogyakarta: Universitas Negeri Yogyakarta.

\section{UCAPAN TERIMAKASIH}

Terima kasih disampaikan kepada Tim Pengabdian STAI Nurul Ilmi Tanjung Balai yang telah mendukung dan memfasilitasi kegiatan Pelatihan Penulisan Karya Ilmiah Dosen pada Juli tahun 2021 sehingga penelitian dan naskah ini dapat terselesaikan dengan baik 